\title{
Articles \\ Wal-Mart Stores v. Dukes: Lessons for the Legal Quest for Equal Pay
}

\author{
DEBORAH THOMPSON EISENBERG*
}

\begin{abstract}
The U.S. Supreme Court's decision in Wal-Mart Stores, Inc. v. Dukes provides a unique opportunity to reflect on whether and how the legal system should address unjustified pay disparities between men and women who perform similar jobs. This Article describes the Court's decision and analyzes the insights it offers about the legal quest for equal pay. First, Wal-Mart demonstrates the tension between Title VII's focus on the employer's intent and the economic realities of how pay discrimination happens in the modern workplace. As the women at Wal-Mart experienced and research confirms, pay disparities tend to be the greatest when employers delegate excessive, unchecked discretion to supervisors. Second, Wal-Mart exemplifies how litigation remedies tend to be ineffective for pay discrimination because of the intent requirement of Title VII, the prima facie standard of substantial equality under the Equal Pay Act, the broad "factor-other-than-sex" defense, and the procedural difficulties for group actions.

This Article proposes a blueprint for a more effective remedy for pay discrimination that would (1) provide incentives for self-regulation by employers, such as pay transparency and periodic compensation audits; (2) limit defenses to those that are job-related and consistent with business necessity; (3) incorporate a pragmatic interpretation of equal work; and (4) facilitate group actions for systemic pay discrimination.
\end{abstract}

${ }^{*}$ Assistant Professor of Law, University of Maryland Francis King Carey School of Law. The author thanks Christine Webber and Debra Gardner for comments, Andrew Montagna for excellent research assistance, and Susan McCarty for citation assistance. 


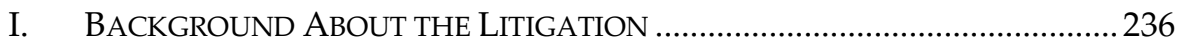

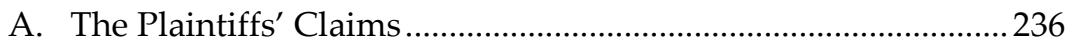

B. Federal Rule of Civil Procedure 23 and Class Certification...... 238

C. Class Action in Wal-Mart ...............................................................2 240

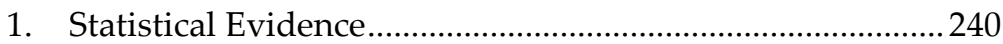

2. Social Framework Testimony …...........................................243

3. Anecdotal Reports of Bias and Gender Stereotyping..........244

D. The Lower Courts' Decisions on Certification ..............................246

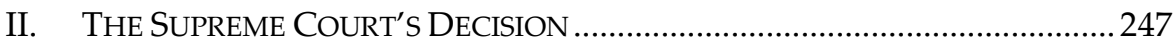

A. Monetary Claims May Not Be Certified Under Federal Rule of Civil Procedure 23(b)(2) ...................................................247

B. Divergent Views on Commonality .............................................. 249

III. LESSONS FOR THE LEGAL QUEST FOR EQUAL PAY .......................................... 255

A. The Dynamics of Pay Discrimination in the Modern Workplace 255

B. The Failure of Litigation Remedies to Address Structural

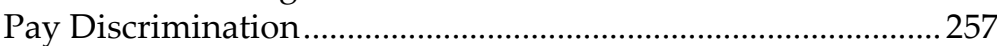

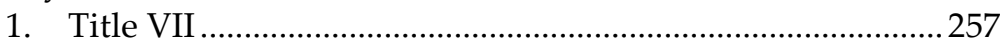

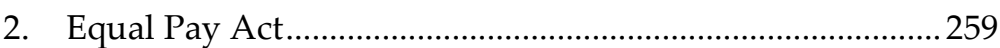

C. Blueprint for an Effective Legal Remedy for Unequal Pay....... 262

1. Incentives for Self-Regulation by Employers .......................263

2. A More Workable Litigation Remedy ....................................2 266

a. The "Bona-Fide-Factor-Other-Than-Sex" Affirmative Defense ..................................................2267

b. A Pragmatic Prima Facie Standard for Similar Work ........................................................................... 268

c. Group Actions for Systemic Pay

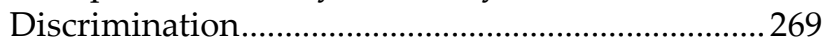

d. Damages............................................................... 270

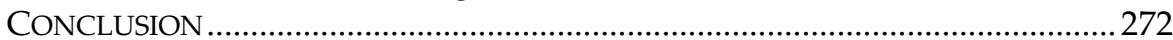




\section{INTRODUCTION}

$\mathrm{I}$

n Wal-Mart Stores, Inc. v. Dukes, ${ }^{1}$ the U.S. Supreme Court held that an estimated 1.5 million current and former female Wal-Mart employees could not challenge discriminatory pay and promotions as a national class action. The Court unanimously held that individualized monetary claims, such as the employees' backpay claims, may not be certified as a class under Federal Rule of Civil Procedure 23(b)(2). ${ }^{2}$ Although four justices would have remanded the case for a determination of whether Plaintiffs could instead proceed as a class under Rule 23(b)(3), ${ }^{3}$ a fivejustice majority cut off that possibility "at the starting gate," ${ }^{4}$ holding that the employees had failed to prove sufficient "commonality" among their claims - one of the threshold requirements for any type of class action. ${ }^{5}$

Wal-Mart has been criticized and praised as representing many different things: the demise of class actions in employment discrimination cases; ${ }^{6}$ a blow to women's equality; ${ }^{7}$ a sensible, unsurprising result given the size of the proposed class; ${ }^{8}$ an example of the Court's whittling away of civil rights by heightening procedural standards; ${ }^{9}$ an example of the pro-

Wal-Mart Stores, Inc. v. Dukes (Wal-Mart III), 131 S. Ct. 2541 (2011).

Id. at 2557-61.

Id. at 2561-62 (Ginsburg, J., concurring in part, dissenting in part). Justice Ginsburg was joined by Justices Breyer, Sotomayor, and Kagan.

Id. at 2562.

Id. at 2556-57 (majority opinion). Justice Scalia wrote for the majority, which included Chief Justice Roberts and Justices Alito, Thomas, and Kennedy.

See Suzette Malveaux, Money Matters, N.Y. TIMES, June 21, 2011, http://www.nytimes.com /roomfordebate/2011/06/20/a-death-blow-to-class-action/money-matters (concluding that the Court's decision "effectively reverses close to 50 years of Title VII jurisprudence and makes it harder for employees to collectively fight systemic discrimination and to be compensated for corporate misconduct").

See Tanya Hernandez, Far From Random Bias, N.Y. TIMES, June 21, 2011, http:// www.nytimes.com/roomfordebate/2011/06/20/a-death-blow-to-class-action/wal-mart-farfrom-random-bias ("Given Wal-Mart's size in the labor market, this court decision not only disserves the plaintiffs' search for justice, it also disserves all women's search for gender equality.").

See John Elwood, Too Many Claims, N.Y. TIMES, June 21, 2011, http://www.nytimes.com /roomfordebate/2011/06/20/a-death-blow-to-class-action/too-many-claims-in-the-wal-mart-vdukes-case ("I expected the court to reject the class claims; the sheer number of putative classmembers (1.5 million), and the nationwide breadth of the company, would have made it very difficult to prove that common acts of discrimination required classwide resolution."); Walter Olson, Wal-Mart v. Dukes: The Court Gets One Right, CATO@LIBERTY (June 20, 2011, 12:57 PM), http://www.cato-at-liberty.org/wal-mart-v-dukes-the-court-gets-one-right/ ("[T]he majority's opinion today is to be preferred as a matter of policy, fairness, and liberty.").

9 See Melissa Hart, Hostility Toward Working Women, N.Y. TIMES, June 21, 2011, http://www 
business bias of the Roberts Court, ${ }^{10}$ and a justified victory for corporate America. ${ }^{11}$ Missing from this commentary is one of the key lessons from this case: the failure of federal law to provide an effective litigation remedy for systemic pay discrimination.

Wal-Mart provides a unique opportunity to reflect on whether and how the legal system should address unjustified pay disparities between men and women.12 Although the Court decided a procedural issue concerning class certification, its ruling was based largely on the underlying remedial scheme of Title VII of the Civil Rights Act of 1964, ${ }^{13}$ the statute under which Plaintiffs sued. As reflected in the majority's opinion, Title VII is a difficult legal remedy for most pay discrimination in the modern workplace. Under the disparate treatment theory of Title VII, the plaintiff must prove that the employer harbored sex-based animus and intentionally paid her less because of her sex. This approach conceptualizes pay discrimination as a civil-rights violation in which the employer deliberately victimizes a woman with lower pay. Indeed, references to Plaintiffs as "victims" of discrimination

.nytimes.com/roomfordebate/2011/06/20/a-death-blow-to-class-action/failing-to-recognizediscrimination ("This creation of heightened standards for class litigation mirrors the heightened pleading standards that the same majority has created out of whole cloth in the recent Iqbal v. Ashcroft and Bell Atlantic Corp. v. Twombly decisions."); see also Barriers to Justice and Accountability: How the Supreme Court's Recent Rulings Will Affect Corporate Behavior: Hearing Before the S. Comm. on the Judiciary, 112th Cong. 5-6, 8 (2011) (prepared testimony of Melissa Hart, Associate Professor, Univ. Colo. Sch. of Law) [hereinafter Hart Testimony], available at http://judiciary.senate.gov/pdf/11-6-29\%20Hart\%20Testimony.pdf.

10 See Alliance for Just., The Corporate COURT's 2010-11 Term: Protecting CORPORATE INTERESTS WHEN IT MATTERS MOST 3 (2011), available at http://www.afj.org/ connect-with-the-issues/the-corporate-court/the-corporate-court-2010-11-end-of-year-

report.pdf ("This was another very good year for corporate interests at the U.S. Supreme Court, and a very bad one for Americans seeking fairness and justice."); Adam Serwer, WalMart v. Dukes: The Difficulty of Proving the Old Boy Network Exists, AM. PROSPECT BLOG (June 20, 2011, 4:00 PM), http://prospect.org/article/wal-mart-v-dukes-difficulty-proving-old-boynetwork-exists (summarizing views that "the success of business interests in the Roberts Court . . reflects not just the attitudes of the conservative majority, but the relatively conservative view of all the justices on the bench on the proper role of the courts").

11 See All Things Considered: Top Court Rules in Favor of Wal-Mart, National Public Radio (June 20, 2011), http://www.npr.org/2011/06/20/137304956/top-court-rules-in-favor-of-walmart ("This is an extremely important victory not just for Wal-Mart but for all companies who do business in the United States." (quoting Wal-Mart's lawyer, Ted Boutrous)); Olson, supra note 8 (stating that "[t]he majority's opinion today is to be preferred as a matter of policy, fairness, and liberty").

12 The plaintiffs in Wal-Mart also alleged discrimination in promotions, but this Article focuses primarily on the compensation issues involved. See Wal-Mart III, 131 S. Ct. 2541, 2548 (2011).

1342 U.S.C. $\S \S 2000$ e to 2000 e-17 (2006). 
pervaded the briefs of the parties and the Court's decision in Wal-Mart. ${ }^{14}$

Title VII's requirement that plaintiffs prove intentional discrimination or "victimization" ignores the complex, subtle realities of pay discrimination. In the modern workplace, pay decisions are increasingly established through more subjective systems, which vest supervisors with significant discretion to vary pay rates for workers performing the same job. Prior research has overwhelmingly shown that the more discretionary the compensation system, the more likely it is that women will experience a gender pay gap. ${ }^{15}$

Plaintiffs in Wal-Mart attempted to show that the company's highly discretionary system for pay and promotions created a pattern or practice of discrimination against female employees in violation of Title VII in three ways. First, Plaintiffs presented detailed statistical evidence about stark pay disparities between men and women performing the same jobs throughout Wal-Mart.16 Second, they offered expert social science testimony to explain how Wal-Mart's discretionary system of decision making for pay and promotions, combined with a strong corporate culture of sex stereotyping, provided a conduit for pay discrimination against women. ${ }^{17}$ Third, Plaintiffs peppered the record with examples of gender bias-more than one hundred anecdotes about supervisors who made explicit sex-based comments or admitted paying women less because they believed men deserved more money as "breadwinners" in their families. ${ }^{18}$

Even with all of this evidence, the majority held that there was not a single common question presented by Plaintiffs sufficient to establish commonality for class certification. Undergirding the majority's opinion is

14 See, e.g., Wal-Mart III, 131 S. Ct. at 2548 (emphasis added) ("[T]hereby making every woman at the company the victim of one common discriminatory practice."); Brief for Petitioner at 17, Wal-Mart III, 131 S. Ct. 2541 (No. 10-277), 2011 WL 201045 (emphasis added) ("Where the plaintiff proves that she is the victim of intentional discrimination . . . [she] has made out a disparate-treatment claim ...."); id. at 33 (emphasis added) ("[S]uch proof would not establish that any other woman in any other store was the victim of intentional discrimination."); Brief for Respondents at 62, Wal-Mart III, 131 S. Ct. 2541 (No. 10-277), 2011 WL 686407 (emphasis added) ("Where a group of victims challenge the same discriminatory employment practice, Rule 23 provides an efficient and economical means of adjudicating these claims."); id. at 63 (emphasis added) ("It is inevitable that the class of victims affected by an allegedly discriminatory workplace practice will include both current and former employees.").

15 Deborah Thompson Eisenberg, Money, Sex, and Sunshine: A Market-Based Approach to Pay Discrimination, 43 ARIZ. ST. L.J. 951, 971-82, 995 (2011) (discussing statistics and numerous studies that show that the wage gap increases for women who have achieved the highest levels of education and professional status and who work the greatest number of hours).

16 See discussion infra Part I.A and accompanying notes.

17 See infra Part I.A and accompanying notes.

18 See infra notes 86-89 and accompanying text. 
the belief that most employers do not intend to pay women less-rather, most pay disparities are the unintended consequence of otherwise sexneutral reasons. As Justice Scalia wrote: "[L]eft to their own devices most managers in any corporation - and surely most managers in a corporation that forbids sex discrimination-would select sex-neutral, performancebased criteria for hiring and promotion that produce no actionable disparity at all." 19

The problem is not Justice Scalia's presumption that most managers would choose not to discriminate. Although intentional pay discrimination undoubtedly continues to exist, many scholars have likewise written that most employers do not intend to pay women less because of their sex..$^{20}$ The issue is that Title VII puts the burden on the plaintiff to prove the discriminatory reasons for the disparity, rather than putting the burden on the employer to prove that pay disparities between employees performing similar jobs are nondiscriminatory and justified. ${ }^{21}$ The Title VII standard diverts attention away from the real problem: the pay disparity itself.

Pay disparities may be caused by a variety of factors that can be discriminatory or non-discriminatory, intentional or unintentional, or structural or individual. Title VII disparate-treatment theory only reaches disparities that are both discriminatory and intentional. Title VII is less effective at attacking pay disparities that may be unintentionally discriminatory, such as those resulting from highly subjective, opaque, or ambiguous compensation schemes. And yet, as existing scholarship explains, most modern-day pay discrimination results from a variety of complex social, cognitive, and situational factors that may not rise to the level of discrimination under Title VII. ${ }^{22}$ Although Title VII disparateimpact theory permits plaintiffs to allege that an otherwise neutral

19 Wal-Mart III, 131 S. Ct. at 2554.

20 Eisenberg, supra note 15, at 986; see also Linda Hamilton Krieger, The Content of Our Categories: A Cognitive Bias Approach to Discrimination and Equal Employment Opportunity, 47 STAN. L. REV. 1161, 1164 (1995) (applying social-cognition theory to explain how discriminatory decisions result from sex stereotypes and unconscious bias); Nicole Buonocore Porter \& Jessica R. Vartanian, Debunking the Market Myth in Pay Discrimination Cases, 12 GeO. J. GENDER \& L. 159, 184 (2011) (explaining how gender schemas affect how employers value women and how women value themselves).

2142 U.S.C. § 2000e-2(k) (2006) (stating that in order to establish a "disparate impact" a complaining party must show that an employer used an otherwise neutral employment policy or practice that has an adverse impact on a protected group).

22 See, e.g., Eisenberg, supra note 15, 961, 966; Barbara J. Flagg, Fashioning a Title VII Remedy for Transparently White Subjective Decisionmaking, 104 YALE L.J. 2009, 2010-14 (1995); Krieger, supra note 20, at 1164-65; David Benjamin Oppenheimer, Negligent Discrimination, 141 U. PA. L. Rev. 899, 899-901 (1993); Porter \& Vartanian, supra note 20, at 184-95; Amy L. Wax, Discrimination as Accident, 74 IND. L.J. 1129, 1330-32 (1999). 
employment policy has discriminatory results, ${ }^{23}$ the Court's holding in Wal-Mart may eviscerate the viability of this theory for many women, particularly national classes.

In the modern workplace, Title VII's intentionality requirement is anachronistic. A remedial framework akin to that of the Federal Equal Pay Act ("EPA") $)^{4}$ provides a more realistic approach for assessing pay discrimination because intent is irrelevant under the EPA. ${ }^{25}$ The EPA focuses on the pay disparity itself, rather than the mindset of the employer. If the plaintiff shows that she is paid less for equal work, ${ }^{26}$ the burden of proof shifts to the employer to prove that the pay disparity is justified by specific, job-related criteria, such as merit or experience. ${ }^{27}$ EPA case law rejects subjective decision making as a proper defense for unequal pay for equal work. ${ }^{28}$

Yet, the plaintiffs in Wal-Mart did not allege violations of the EPA-a strategic decision that is not unusual or surprising. Although the EPA

23 See Watson v. Fort Worth Bank \& Trust, 487 U.S. 977, 986-87, 991 (1988) (holding that disparate-impact theory may be applied to a subjective or discretionary promotion system); Griggs v. Duke Power Co., 401 U.S. 424, 430, 436 (1971) (holding that employer's requirement of high school education and passage of standardized general intelligence test had disparate impact on black employees in violation of Title VII).

2429 U.S.C. § 206(d) (2006).

25 See Mickelson v. N.Y. Life Ins. Co., 460 F.3d 1304, 1310-11 (10th Cir. 2006) (explaining that the EPA imposes "a form of strict liability on employers who pay males more than females for performing the same work -in other words, the plaintiff ... need not prove that the employer acted with discriminatory intent").

${ }^{26}$ A plaintiff establishes a prima facie case under the EPA by proving that she and a male employee were paid differently for "equal work on jobs the performance of which requires equal skill, effort, and responsibility, and which are performed under similar working conditions ...." 29 U.S.C. § 206(d)(1).

7 Corning Glass Works v. Brennan, 417 U.S. 188, 196-97 (1974) (explaining that employer bears burden of proof on affirmative defenses). The EPA has four exceptions to the mandate of equal pay for equal work. The employer may prove that the pay disparity was "made pursuant to (i) a seniority system; (ii) a merit system; (iii) a system which measures earnings by quantity or quality of production; or (iv) a differential based on any other factor other than sex ...." 29 U.S.C. $\S 206(d)(1)$.

28 See, e.g., EEOC v. White \& Son Enters., 881 F.2d 1006, 1009-10 (11th Cir. 1989) (holding that employer's defense failed because the company had no written or objective system of setting wages); Keziah v. W.M. Brown \& Son, Inc., 888 F.2d 322, 326 (4th Cir. 1989) (“One of the things undermining the company's defense is the pure subjectivity of the salary-setting process."); Brennan v. Victoria Bank \& Trust Co., 493 F.2d 896, 902 (5th Cir. 1974) ("[S]ubjective evaluations of the employer cannot stand alone as a basis for salary discrimination based on sex."); Hodgson v. Brookhaven Gen. Hosp., 436 F.2d 719, 726 (5th Cir. 1970) (recognizing that permitting a defense to pay disparities based on assertions of "merit" and "performance," "if not strictly construed against the employer, could easily 'swallow the rule'”). 
provides a more realistic conceptual model for pay discrimination, the statute imposes steep litigation hurdles on plaintiffs. First, the EPA has a threshold prima-facie standard of substantial equality between compared positions. Some courts have interpreted this standard so strictly as to exclude most working women-especially those in higher-level jobs and non-assembly line positions - from the Act's coverage..$^{29}$ Second, the EPA includes a catch-all "factor-other-than-sex" affirmative defense, which some courts have interpreted broadly to immunize employers from liability.30 Finally, the EPA prohibits class actions and requires each plaintiff to file an individual consent form with the court indicating her desire to "opt in" to the collective action. ${ }^{31}$ This increases the administrative and discovery costs of group actions under the EPA. It also deters many women from joining cases because they may fear retaliation for stepping forward, whereas being a class member under Rule 23 does not leave them feeling so exposed.

This Article applies lessons from the Wal-Mart case to the quest for a more effective remedy for unequal pay for equal work. Looking through the lens of the Court's decision, the Article explains the shortfalls of current equal-pay laws and offers a blueprint for a more effective legal remedy for pay discrimination. Part I summarizes Plaintiffs' claims and the lower courts' class certification decisions. Part II analyzes the Court's holding. Part III explains why current federal statutory remedies for pay discrimination-Title VII and the EPA-increasingly fail in the courts. It also proposes amendments that would make the EPA and the proposed Paycheck Fairness Act more compatible with the realities of pay discrimination.

\section{Background About the Litigation}

\section{A. The Plaintiffs' Claims}

On June 16, 2001, six women who worked for Wal-Mart Stores, Inc. ${ }^{32}$ filed a complaint, on behalf of themselves and all women similarly situated, in the United States District Court, Northern District of California, in San Francisco. Plaintiffs alleged two types of sex discrimination under Title VII: disparate treatment ${ }^{33}$ and disparate impact. ${ }^{34}$ Plaintiffs had two

29 Deborah Thompson Eisenberg, Shattering the Equal Pay Act's Glass Ceiling, 63 SMU L. REV. 17, 37-41 (2010).

30 See id. at 57-61.

1 See 29 U.S.C. § 216(b).

32 Plaintiffs worked for both Wal-Mart stores and Sam's Club stores throughout the United States. Wal-Mart III, 131 S. Ct. 2541, 2547-48 (2011).

33 Disparate treatment has been defined as "the most easily understood type of 
general contentions. They claimed, first, that women employed at WalMart "are paid less than men in comparable positions, despite having higher performance ratings and greater seniority," 35 and second, that women "receive fewer promotions to in-store management positions than do men, and those who are promoted must wait longer than their male counterparts to advance." 36 Plaintiffs alleged that "their local managers' discretion over pay and promotions [was] exercised disproportionately in favor of men, leading to an unlawful disparate impact on female employees." ${ }^{37}$ In addition, "because Wal-Mart [was] aware of this effect, its refusal to cabin its managers' authority amount[ed] to disparate treatment." 38

Plaintiffs claimed that Wal-Mart's discriminatory pay and promotion practices resulted from the company's highly subjective personnel system, which placed substantial discretion in the hands of store managers. For example, rather than post available promotional opportunities and consider applicants based on objective job-related criteria, Wal-Mart used a "tap on the shoulder" system in which predominantly male "managers ha[d] discretion about whose shoulders to tap." ${ }^{39}$ As a result of this system, women "had no ability to apply for, or otherwise formally express their interest in, openings as they arose," and "[m]anagers did not have to consider all interested and qualified candidates, thus further intensifying the subjective nature of the promotion process." 40

In addition, store managers exercised substantial discretion in setting hourly pay rates. Wal-Mart left “open a $\$ 2$ band for every position's hourly pay rate." 41 The company provided "no standards or criteria for setting

discrimination. The employer simply treats some people less favorably than others because of their race, color, religion, sex, or national origin." Int'l Bhd. of Teamsters v. United States, 431 U.S. 324, 335 n.15 (1977).

${ }^{34}$ In a disparate-impact case, the plaintiff alleges that an otherwise neutral employment practice has a discriminatory effect on a protected class. "[A] plaintiff establishes a prima facie disparate-impact claim by showing that the employer uses a particular employment practice that causes a disparate impact on one of the prohibited bases" under Title VII. Lewis v. City of Chi., 130 S. Ct. 2191, 2197 (2010) (internal quotation marks omitted); see, e.g., Watson v. Fort Worth Bank \& Trust, 487 U.S. 977, 989-91 (1988); Hazelwood Sch. Dist. v. United States, 433 U.S. 299, 301-04 (1977).

35 Dukes v. Wal-Mart Stores, Inc. (Wal-Mart I), 222 F.R.D. 137, 141 (N.D. Cal. 2004).

${ }^{36} \mathrm{Id}$.

37 Wal-Mart III, 131 S. Ct. at 2548.

${ }^{38} \mathrm{Id}$.

39 Id. at 2563 (Ginsburg, J., concurring in part, dissenting in part) (internal quotation marks omitted).

40 Brief for Respondents, supra note 14, at 18 (quoting Wal-Mart I, 222 F.R.D. at 149).

41 Wal-Mart III, 131 S. Ct. at 2563 (Ginsburg, J., dissenting). 
wages within that band, and thus [did] nothing to counter unconscious bias on the part of supervisors." 42 For example, a male "greeter" saying hello to customers at the entrance, a male cashier scanning items at checkout, or a male stocker putting items on shelves, could make up to two dollars more than female co-workers doing exactly the same job. As women moved up the leadership ladder at Wal-Mart, both the level of discretion in pay-setting and the gender pay gap increased dramatically. ${ }^{43}$

\section{B. Federal Rule of Civil Procedure 23 and Class Certification}

Ten years after Plaintiffs filed suit, the merits of their claims have not been addressed by any court. The preliminary procedural question facing the Supreme Court was whether all women who worked for Wal-Mart who were subjected to discriminatory pay and promotion practices could proceed as a class under Federal Rule of Civil Procedue 23. To understand the Court's decision and the arguments of the parties, some preliminary background about class action requirements is in order.

A class action is typically used when multiple plaintiffs allege a similar legal violation against the same defendant, and the costs of proceeding individually would be too high, often because the individual plaintiffs' claims are too low to attract competent counsel to bring the case. Class actions promote judicial economy by allowing one court to decide common questions of fact or law, rather than having thousands-or millions-of separate lawsuits sprinkled throughout the country that may have inconsistent results. ${ }^{44}$

In a class action, a handful of "named plaintiffs" on the complaint seek to represent all absent class members who have similar claims against the same defendant. If the class is certified, any judgment in the case will be binding on all class members. To succeed on a motion for class certification under Federal Rule of Civil Procedue 23, the representative plaintiffs must first show that they satisfy four threshold requirements: (1) numerosity; 45 (2) commonality; ${ }^{46}$ (3) typicality;7 and (4) adequacy of representation. ${ }^{48}$

${ }^{42} I d$.

43 See infra notes 60-76 and accompanying text.

44 James M. Finberg, Class Actions: Useful Devices that Promote Judicial Economy and Provide Access to Justice, 41 N.Y.L. SCH. L. REV. 353, 353 (1997); see also Rachel Tallon Pickens, Too Many Riches?: Dukes v. Wal-Mart and the Efficacy of Monolithic Class Actions, 83 U. DET. MERCY L. REv. 71, 73 (2006) ("[C]lass actions encourage judicial economy and maximize efficiency by preventing duplicative lawsuits and preventing inconsistent adjudications.").

45 FED. R. CIV. P. 23(a)(1) (stating that one or more members may sue or be sued as class representative if "the class is so numerous that joinder of all members is impracticable").

$46 I d$. at 23(a)(2) (stating that one or more members may sue or be sued as class representative if "there are questions of law or fact common to the class"). 
If these four prerequisites are satisfied, the court may certify one of three types of class actions. First, a court may certify a class under Rule 23(b)(1) if it finds that "prosecuting separate actions by or against individual class members would create a risk of" either inconsistent verdicts or standards of conduct for the defendant opposing the class ${ }^{49}$ or verdicts that could "substantially impair or impede" the rights of others who are not parties to the individual litigation. ${ }^{50}$ Second, a court may certify a class under Rule 23(b)(2) if "the party opposing the class has acted or refused to act on grounds that apply generally to the class, so that final injunctive relief or corresponding declaratory relief is appropriate respecting the class as a whole." 51 Finally, a class may be certified under Rule 23(b)(3) if "the court finds that the questions of law or fact common to class members predominate over any questions affecting only individual members, and that a class action is superior to other available methods for fairly and efficiently adjudicating the controversy." 52

A class certified under Rule 23(b)(3) has greater protections for absent class members. Whereas "the court may direct appropriate notice to the class" under Rule (b)(1) or (b)(2), 53 "the court must direct to class members the best notice that is practicable under the circumstances" for a (b)(3)

47 Id. at 23(a)(3) (stating that one or more members may sue or be sued as class representative if "the claims or defenses of the representative parties are typical of the claims or defenses of the class").

48 Id. at 23(a)(4) (stating that one or more members may sue or be sued as class representative if "the representative parties will fairly and adequately protect the interests of the class").

49 Id. at 23(b)(1)(A); see, e.g., Benjamin Kaplan, Continuing Work of the Civil Committee: 1966 Amendments of the Federal Rules of Civil Procedure (I), 81 HARV. L. REV. 356, 388 (1967) (footnotes omitted) ("[This rule] takes in cases where the party is obliged by law to treat the members of the class alike ([e.g.,] a utility acting toward customers; a government imposing a tax), or where the party must treat all alike as a matter of practical necessity ([e.g.,] a riparian owner using water as against downriver owners).").

50 FED. R. CIV. P. 23(b)(1)(B); see, e.g., Amchem Prods., Inc. v. Windsor, 521 U.S. 591, 614 (1997) ("Rule 23(b)(1)(B) includes, for example, 'limited fund' cases, instances in which numerous persons make claims against a fund insufficient to satisfy all claims.").

51 FED. R. CIV. P. 23(b)(2); see, e.g., Amchem Prods., 521 U.S. at 614 ("Civil rights cases against parties charged with unlawful, class-based discrimination are prime examples [of actions brought under this Rule].").

52 FED. R. CIV. P. 23(b)(3); see Amchem Prods., 521 U.S. at 615 (explaining that the "predominance" and "superiority" requirements were added to Rule 23(b)(3) "to cover cases 'in which a class action would achieve economies of time, effort, and expense, and promote . . . uniformity of decision as to persons similarly situated, without sacrificing procedural fairness or bringing about other undesirable results."' (quoting FED. R. CIV. P. 23 advisory committee's note subdivision (b)(3) (1966))).

53 FED. R. CIV. P. 23(c)(2)(A) (emphasis added). 
class. ${ }^{54}$ Any judgment in a class case will apply to all class members whether they are named plaintiffs or absent class members. ${ }^{55}$ The notice requirement for Rule 23(b)(3) classes advises absent class members that any judgment will be binding on them and allows them to "opt out" or request that they be excluded from the class. ${ }^{56}$

\section{Class Action in Wal-Mart}

The core questions before the Court in Wal-Mart were: (1) Was the class properly certified under Rule 23(b)(2) given the substantial claims for backpay;5 and (2) Did the class satisfy the threshold requirement of "commonality"?58 Plaintiffs argued that their claims for backpay could be certified under Rule 23(b)(2) because backpay is an equitable remedy that was incidental in nature to the injunctive and declaratory relief sought. ${ }^{59}$ Plaintiffs presented three different types of evidence to establish commonality of the class members' claims: statistical evidence, socialframework testimony, and anecdotal reports of bias and gender stereotyping.

\section{Statistical Evidence}

To demonstrate "common questions" about gender disparities in pay and promotions throughout the company, Plaintiffs presented the expert testimony of a statistician, Dr. Richard Drogin. ${ }^{60}$ Dr. Drogin analyzed WalMart's payroll and personnel data. He conducted statistical regressions for hourly and salaried employees, controlling for a variety of factors such as: "gender, length of time with the company, number of weeks worked during the year, whether the employee was hiring [sic] or terminated during the year, full-time or part-time, which store the employee worked in, whether the employee was ever hired into a management position, job position, and job review ratings." 61 Dr. Drogin found that "in every one of Wal-Mart's 41 regions women were paid significantly less than men, and this pay gap increased each year." 62 The data showed that more women

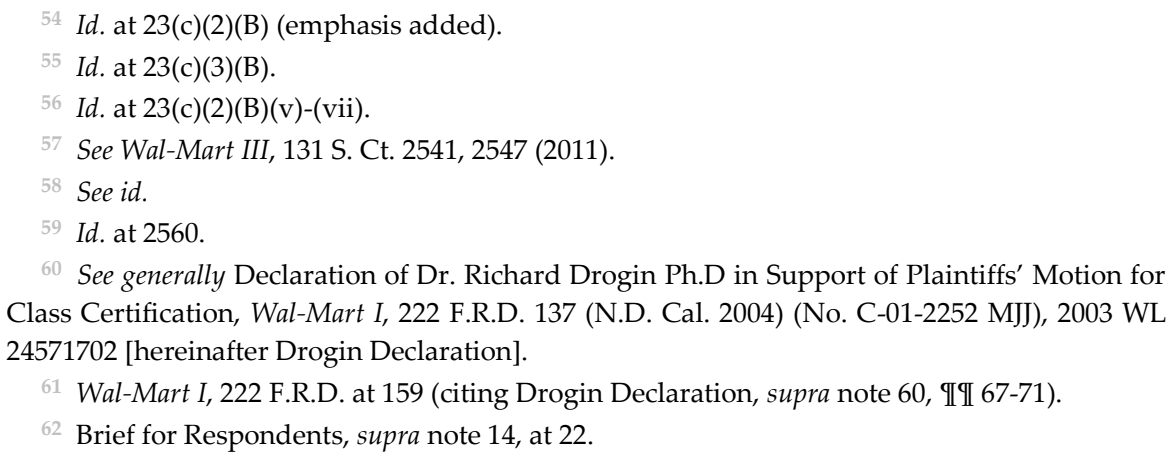


than men worked for Wal-Mart and that women overall had more seniority (4.47 years) than men (3.13 years). ${ }^{63}$ On average, women in hourly positions also had higher performance ratings (3.91) than their male counterparts (3.84). ${ }^{64}$ Nevertheless, Dr. Drogin found that men performing the same hourly jobs as women had higher hourly rates and that the pay gap increased over time. ${ }^{65}$ For example, he found that such men earned \$0.35 more per hour when hired, but that gap increased to $\$ 1.16$ per hour on average over a five-year period. ${ }^{66}$ Plaintiffs also argued that certain lowerpaid departments were female-dominated, and certain higher-paid departments were male dominated. ${ }^{67}$ Significantly, prior to Plaintiffs' suit, Wal-Mart's pay guidelines did not identify "department" as a factor to be considered in setting pay, and employees had the same job titles for clerks working in all departments.

Overall, Dr. Drogin found that "women earned about \$5,200 less than men, on the average, in 2001. Within the hourly workforce, women earned about $\$ 1,100$ less than men, and about $\$ 14,500$ less among management employees, in 2001."68 Plaintiffs presented the following chart from Dr. Drogin's analysis that shows the disparities in average earnings between men and women performing the same jobs ${ }^{69}$ :

63 Drogin Declaration, supra note 60, II 28, at 18 tbl.12.

${ }^{64}$ Id. II 30, at 19 tbl.13.

65 Brief for Respondents, supra note 14, at 22.

66 Drogin Declaration, supra note 60, II 33.

67 Wal-Mart I, 222 F.R.D. 137, 147 (N.D. Cal. 2004) (citing Drogin Declaration, supra note 60, II 23, at 13-14 tbl.7)

68 Drogin Declaration, supra note 60, II 20.

69 Plaintiffs' Motion for Class Certification \& Memorandum of Points and Authorities at 26, Wal-Mart I, 222 F.R.D. 137 (No. C-01-2252 MJJ) [hereinafter Plaintiffs' Motion for Class Certification] (citing Drogin Declaration, supra note 60, III 25-26, at 16-17 tbls.9 \& 10). 


\begin{tabular}{|l|l|l|l|}
\hline \multicolumn{2}{|l|}{ Average Earnings by Gender for 2001} & \multicolumn{2}{l|}{} \\
\hline Job & Men & Women & Difference \\
\hline Regional Vice Pres. & $\$ 419,435$ & $\$ 279,772$ & $\$ 139,663$ \\
\hline District Manager & $\$ 239,519$ & $\$ 177,149$ & $\$ 62,370$ \\
\hline Store Manager & $\$ 105,682$ & $\$ 89,280$ & $\$ 16,402$ \\
\hline Co-Manager & $\$ 59,535$ & $\$ 56,317$ & $\$ 3218$ \\
\hline Asst. Manager & $\$ 39,790$ & $\$ 37,322$ & $\$ 2468$ \\
\hline Mgmt. Trainee & $\$ 23,175$ & $\$ 22,371$ & $\$ 804$ \\
\hline Dept. Head & $\$ 23,518$ & $\$ 21,709$ & $\$ 1809$ \\
\hline Sales Associate & $\$ 16,526$ & $\$ 15,067$ & $\$ 1459$ \\
\hline Cashier & $\$ 14,525$ & $\$ 13,831$ & $\$ 694$ \\
\hline
\end{tabular}

Dr. Drogin found a statistically significant "gender hierarchy" at WalMart, with women disproportionately employed in lower-paying hourly jobs in each of Wal-Mart's forty-one regions. ${ }^{70}$ Women performed about $65 \%$ of the hourly jobs, but they held only $33 \%$ of the management positions. ${ }^{71}$ This imbalance was particularly striking because a large percentage of store management was promoted from within the hourly ranks. Dr. Drogin found a statistically significant shortfall of women who were promoted to each category of management positions in all of WalMart's regions. ${ }^{72}$ For those women who were promoted, it took them longer to move up the ladder: It took men, on average, 2.86 years from date of hire to be promoted to assistant manager as compared to 4.38 years for women. ${ }^{73}$ To reach store manager, women on average took 10.12 years from hire date, compared with 8.64 years from hire for male employees. ${ }^{74}$

To rebut any suggestion that women were simply less interested in working in management positions, ${ }^{75}$ Plaintiffs also presented the testimony

${ }^{0}$ Drogin Declaration, supra note 60, II 77(a).

1 Id. II 19.

72 Wal-Mart I, 222 F.R.D. at 160-61 (citing Drogin Declaration, supra note 60, II 63).

3 Id. at 161 (citing Drogin Declaration, supra note 60, II 29).

${ }^{4}$ Id.

${ }^{5}$ Employers frequently argue that women are poorly represented in certain types of jobs because they lack interest in the positions. For analysis of the "lack of interest" defense in Title VII cases, see generally Vicki Schultz \& Stephen Petterson, Race, Gender, Work, and Choice: An Empirical Study of the Lack of Interest Defense in Title VII Cases Challenging Job Segregation, 59 U. CHI. L. REV. 1073 (1992) and Vicki Schultz, Telling Stories About Women and Work: Judicial Interpretations of Sex Segregation in the Workplace in Title VII Cases Raising the Lack of Interest 
of labor economist Marc Bendick, who found that Wal-Mart seriously lagged behind other retail stores in terms of representation of women in management positions. He conducted a benchmarking analysis for the period 1975-2002 and found that Wal-Mart had a consistent shortfall in female managerial representation in every year examined. ${ }^{76}$ Dr. Bendick concluded: "The scale, pervasiveness, persistence, and consistency of under-representation of women among Wal-Mart's managers suggests that such under-representation is deeply rooted in the organization's corporate culture and the company-wide employment attitudes, policies and practices that reflect and maintain that culture."77 In fact, Wal-Mart had conducted its own internal benchmarking studies, which showed that as compared to its retail competitors, "Wal-Mart had a 'gap' of 3324 women managers." 78

\section{Social Framework Testimony}

Plaintiffs also presented evidence of a social-science expert, Dr. William Bielby. ${ }^{79}$ Dr. Bielby testified "that Wal-Mart's strong centralized common culture sustained uniformity of decision-making, that its highly subjective system was vulnerable to sexual stereotyping, and that its diversity policies failed to mitigate the effect of stereotyping." ${ }^{80} \mathrm{He}$ further explained social-science research demonstrates that subjective decision making permits gender stereotypes to influence personnel decisions because discretion allows "people to 'seek out and retain stereotypingconfirming information and ignore or minimize information that defies stereotypes.'" $81 \mathrm{He}$ found that at Wal-Mart "managers make decisions with considerable discretion and little oversight." 82 He concluded that such subjective pay and promotion decisions "are likely to be biased 'unless they are assessed in a systematic and valid manner, with clear criteria and careful attention to the integrity of the decision-making process.'" 83 Based on a review of the depositions of managers and Wal-Mart's personnel

\footnotetext{
Argument, 103 HARV. L. REV. 1749 (1990).

76 Declaration of Marc Bendick, Jr. Ph.D in Support of Plaintiffs' Motion for Class Certification II 52, at 25, Wal-Mart I, 222 F.R.D. 137 (No. C-01-2252 MJJ), 2003 WL 24571703 [hereinafter Bendick Declaration].

77 Id. II 67, at 32.

78 Plaintiffs' Motion for Class Certification, supra note 69, at 31.

79 See generally Declaration of William T. Bielby, Ph.D in Support of Plaintiffs' Motion for Class Certification, Wal-Mart I, 222 F.R.D. 137 (No. C-01-2252 MJJ), 2003 WL 24571701 [hereinafter Bielby Declaration].

${ }^{80}$ Brief for Respondents, supra note 14, at 7.

81 Wal-Mart I, 222 F.R.D. at 153 (quoting Bielby Declaration, supra note 79, II 34, at 19-20).

${ }^{82}$ Id. (quoting Bielby Declaration, supra note 79, IIII 37-41, at 21-24).

83 Id. (quoting Bielby Declaration, supra note 79, II 39, at 23).
} 
policies, Dr. Bielby concluded:

In sum, consistent with the organizational research on this topic, Wal-Mart's distinctive corporate culture is sustained by focused efforts of the firm through on-going training and socialization, communication specifically designed to reinforce its distinctive elements, promotion from within and relocating managers from store to store, and shared experiences among employees that build commitment to shared beliefs and values. As a result of these efforts, employees achieve a common understanding of the company's ways of conducting business. ${ }^{84}$

The district court found that "Dr. Bielby's testimony raise[d] an inference of corporate uniformity and gender stereotyping that is common to all class members." 85

\section{Anecdotal Reports of Bias and Gender Stereotyping}

In addition to expert testimony, Plaintiffs submitted declarations of 120 women who worked at Wal-Mart stores throughout the nation. These declarations testified "to being paid less than similarly situated men, being denied promotion or being delayed in promotion in a disproportionate manner compared with similarly situated men, working in an atmosphere with a strong corporate culture, and being subjected to various individual sexist acts." 86 The women reported that managers told them-sometimes in especially sexist terms - that retail management was not an appropriate job for women. ${ }^{87}$ Wal-Mart imposed certain requirements for promotion that

${ }^{84}$ Id. at 152 (quoting Bielby Declaration, supra note 79, II 21, at 12).

85 Id. at 154.

${ }^{86}$ Id. at $165-66$.

87 A footnote in the Plaintiffs' Motion for Class Certification summarized some of these stereotypical comments about the appropriateness of women for managerial positions:

See, e.g., Durfey Decl. at II 10 (a female assistant manager in Utah was told repeatedly by a store manager that retail is "tough" and not "appropriate" for women); Scott Decl. at III 8, 9, 12 (male store manager told Scott that " $[\mathrm{m}] \mathrm{en}$ are here to make a career and women aren't. Retail is for housewives who just need to earn extra money"); Mathis Decl. at II 12 (male store manager told female associate that women have to be "bitches" to survive in Wal-Mart management); Kwapnoski Decl. at II 16 (female receiving area manager told by store manager to "doll-up," dress a little better and "blow the cobwebs off [her] make-up"); Lovejoy Decl. at II 6 (male area manager told female associate that she could not get promoted to the overnight supervisor position because she had children and because she would be the only woman working overnight); Zumbrun Decl. at II 5 (during interview for ICS team leader, male assistant manager asked her, "[b]eing a female, what makes you more qualified for this job than a male employee?" She was also told that the ICS staff was mostly 
adversely impacted women, including a relocation requirement, participation in hunting retreats, and attendance at management meetings at Hooters or strip clubs. ${ }^{88}$ Women reported being called "little Janie Qs" and "girls." 89 They also cited instances in which supervisors told them that women received lower pay because men deserved more money to support their families..$^{90}$

male and that they might have a problem with a female boss; male was hired); Donovan Decl. at II 6 (male manager told her "you aren't part of the boy's club, and you should raise a family and stay in the kitchen" instead of seeking advancement); Martin Decl. at II 13 (told by male comanager, "you need to grow some balls"); Rajas Decl. at II 5 (male district manager told her to resign as an Assistant Manager and find a husband with whom she could settle down to relieve work-related stress); Deno Dep. at 166:15-167:7, 234:2-236:6, Ex. 69 (male manager said women only made store manager to meet a quota, that women should be home barefoot and pregnant and women weren't qualified to be managers because men had an extra rib).

Plaintiffs' Motion for Class Certification, supra note 69, at 16 n.9.

88 See Declaration of Melissa Howard in Support of Plaintiffs' Motion for Class Certification III 14, 17-19, Wal-Mart I, 222 F.R.D. 137 (N.D. Cal. 2004) (No. C-01-2252 MJJ), available at www.walmartclass.com/staticdata/walmartclass/declarations/Howard_Melissa .htm.

39 Plaintiffs' Motion for Class Certification, supra note 69, at 13.

90 Plaintiffs provided the following examples of women being told that they were being paid less because of their sex:

Tallent Decl. at II 10 (during department manager meeting, male store manager said, "[m]en need to be paid more than women because they have families to support"); Young Decl. at II 10 (during store meeting, male assistant manager responded to question from female associate about why men made more than women by stating that men were working as heads of their households while women were just working for the sake of working); Scott Decl. at II 8 (when single mother personnel manager asked why male associate was receiving a merit raise, male assistant manager told her it was because he "has a family to support"); Kwapnoski Decl. at II 12 (store manager told plaintiff that he gave male associate larger raise because he had "a family to support"); McDonald Decl. at II 7 (female associate told by male Department Manager that male employees will always make more than females because "God made Adam first, so women would always be second to men"); Odle Decl. at III 8, 10, 11 (when female assistant manager requested raises for two female associates because they were making less than their male counterparts, male general manager said, "[t]hose girls don't need any more money; they make enough as it is." She later asked why a male assistant manager was making over $\$ 10,000$ more than she was, male director of operations told him it was because he "supports his wife and his two kids"); Brown Decl. at II 5 (when she asked department manager 
Ultimately, Plaintiffs identified the following common questions of fact and law:

(1) Does Wal-Mart have a largely subjective compensation and promotion system; (2) Does that system result in lower pay and fewer promotions for women; (3) Does Wal-Mart's strong corporate culture contribute to discrimination against women in pay and promotion; (4) Which statistical analysis most accurately measures the disparities between male and female employees; (5) Was Wal-Mart's senior management aware that its subjective personnel system was resulting in adverse outcomes for women; and (6) Can Wal-Mart's subjective personnel system be justified as a "business necessity" and, if so, were there "less discriminatory alternatives" ?91

These common questions of fact formed the basis of Plaintiffs' argument for class certification.

\section{The Lower Courts' Decisions on Certification}

After reviewing a voluminous record and holding hearings, the U.S. District Court for the Northern District of California, in an eighty-four page order, certified a class consisting of "[a]ll women employed at any WalMart domestic retail store at any time since December 26, 1998, who have been or may be subjected to Wal-Mart's challenged pay and management track promotions policies and practices." 92 The court modified the class in two ways. First, it "excluded backpay claims based on promotion opportunities that had not been publicly posted, for the reason that no applicant data could exist for such positions." ${ }^{93}$ In addition, it "decided to afford class members notice of the action and the right to "opt out" of the class with respect to [the] punitive-damages claim." ${ }^{\prime 94}$

The United States Court of Appeals for the Ninth Circuit, on rehearing en banc, affirmed the district court's certification order. ${ }^{95}$ The majority found that Plaintiffs" evidence "raise[d] the common question whether Wal-Mart's female employees nationwide were subjected to a single set of corporate policies (not merely a number of independent discriminatory acts) that may have worked to unlawfully discriminate against them in

\footnotetext{
about why her pay was lower than a less qualified male, manager said, "[y]ou don't have the right equipment . . . you aren't male, so you can't expect to be paid the same.").

Id. at 17-18 n.10.

${ }^{1}$ Brief for Respondents, supra note 14, at 15 (citations omitted).

2 Wal-Mart I, 222 F.R.D. at 188.

Wal-Mart III, 131 S. Ct. 2541, 2549 n.3 (2011) (citing Wal-Mart I, 222 F.R.D. at 182).

94 Id. (citing Wal-Mart I, 222 F.R.D. at 173).

95 Dukes v. Wal-Mart Stores, Inc. (Wal-Mart II), 603 F.3d 571, 577 (9th Cir. 2010).
} 
violation of Title VII."96 The Ninth Circuit affirmed the certification of Plaintiffs' backpay claims under Rule 23(b)(2) but adjusted the class in two ways. First, the court "remanded that part of the certification order which included [Plaintiffs'] punitive-damages claim in the (b)(2) class, so that the District Court might consider whether that might cause the monetary relief to predominate." ${ }^{97}$ Second, in response to Wal-Mart's argument that class members who no longer worked at Wal-Mart lacked standing to seek injunctive and declaratory relief, it excluded "those putative class members who were no longer Wal-Mart employees at the time Plaintiffs' complaint was filed." 98

\section{The Supreme Court's Decision}

\section{A. Monetary Claims May Not Be Certified Under Federal Rule of Civil Procedure 23(b)(2).}

The Court unanimously held that claims for monetary relief may not be certified under Federal Rule of Civil Procedure 23(b)(2)..$^{99}$ This provision permits class certification when "the party opposing the class has acted or refused to act on grounds that apply generally to the class, so that final injunctive relief or corresponding declaratory relief is appropriate respecting the class as a whole." 100

Instead, the Court instructed that claims for individualized monetary relief are more appropriately certified under Federal Rule of Civil Procedure 23(b)(3), which provides greater procedural protections.101 Whereas a class certified under Rule 23(b)(2) is "mandatory" - meaning that individual class members do not receive notice and an opportunity to "opt out" of the action-a class certified under Rule 23(b)(3) requires that class members receive "the best notice that is practicable under the circumstances" and the opportunity to "opt out" of the case and pursue (or not pursue) their own action. ${ }^{102}$ The Court stated that "[i]n the context of a class action predominately for money damages we have held that absence of notice and opt out violates due process." 103

The Court rejected Plaintiffs' argument that the backpay claims could be certified under Rule 23(b)(2) because they did not "predominate" over

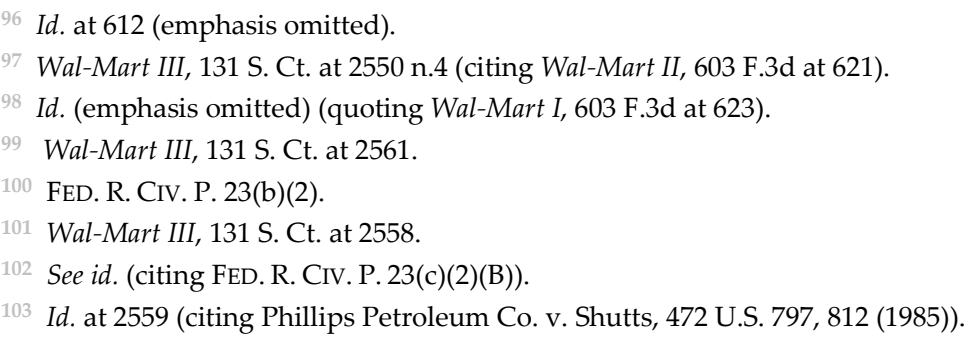


their requests for injunctive and declaratory relief. ${ }^{104}$ The Court concluded that even if the injunctive claim under Rule 23(b)(2) predominated over the monetary claims, the procedural protections in Rule 23(b)(3) for monetary claims are still required. ${ }^{105}$ It cautioned that Plaintiffs' "predominance test" would also create a "perverse incentive[] for class representatives to place at risk potentially valid claims for monetary relief."106 In the district court, for example, Plaintiffs did not assert claims for compensatory damages. ${ }^{107}$ The Ninth Circuit had also limited the class to those women employed at Wal-Mart as of the filing date of the complaint to ensure that all plaintiffs had standing to seek injunctive or declaratory relief and that backpay claims did not predominate. ${ }^{108}$ The Court rejected such procedural wrangling to try to squeeze the class under Rule 23(b)(2) rather than Rule 23(b)(3)..$^{109}$

The Court rested its holding largely on the due process rights of the employer under Title VII, stating that "Wal-Mart is entitled to individualized determinations of each employee's eligibility for backpay." ${ }^{110}$ The Court reviewed Title VII's "detailed remedial scheme," which affords the defendant the opportunity to "show that it took an adverse employment action against an employee for any reason other than discrimination." 111 The Court stated that if a plaintiff makes a showing of discrimination in a Title VII pattern-and-practice case, the defendant then has "the right to raise any individual affirmative defenses it may have, and to 'demonstrate that the individual applicant was denied an employment opportunity for lawful reasons.'"112

The Court held that the Ninth Circuit erred in replacing individualized determinations of all potential defenses with "Trial by Formula."113 The Ninth Circuit had approved a sampling procedure to determine damages based on a prior ruling in Hilao v. Estate of Marcos. ${ }^{114}$ The Court described the "Trial by Formula" process as follows:

A sample set of the class members would be selected, as to whom liability for sex discrimination and the backpay owing as a result

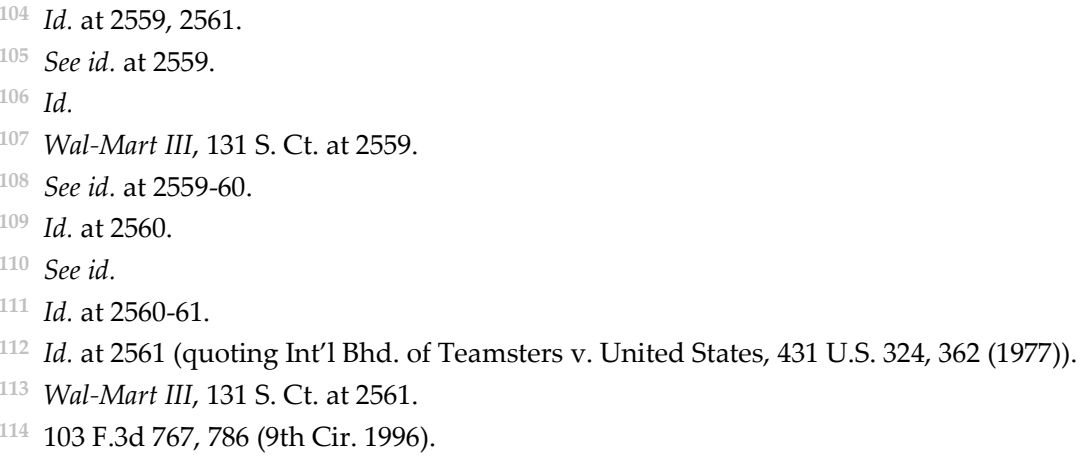


would be determined in depositions supervised by a master. The percentage of claims determined to be valid would then be applied to the entire remaining class, and the number of (presumptively) valid claims thus derived would be multiplied by the average backpay award in the sample set to arrive at the entire class recovery-without further individualized proceedings. 115

The Court rejected the sampling method for determining damages "[b]ecause the Rules Enabling Act forbids interpreting Rule 23 to 'abridge, enlarge or modify any substantive right."'116 The Court concluded that "a class cannot be certified on the premise that Wal-Mart will not be entitled to litigate its statutory defenses to individual claims."117 In other words, a representative sampling of trials would deny Wal-Mart its substantive right under Title VII to proffer legitimate, non-discriminatory reasons for every alleged act of discrimination. And because individualized trials would be required for all 1.5 million members of the class, the Court held that the backpay claims could not be "incidental" to the injunctive and declaratory relief. ${ }^{118}$ Therefore, the class could not be certified under Rule 23(b)(2). ${ }^{119}$

\section{B. Divergent Views on Commonality}

In a 5-4 vote, the Court split on whether Plaintiffs satisfied the threshold class prerequisite of "commonality." Prior to the Court's decision in Wal-Mart, the requirement to show "commonality" among members of a class was not considered onerous. ${ }^{120}$ The district court identified, and the Ninth Circuit affirmed, a common question: “Whether Wal-Mart's pay and

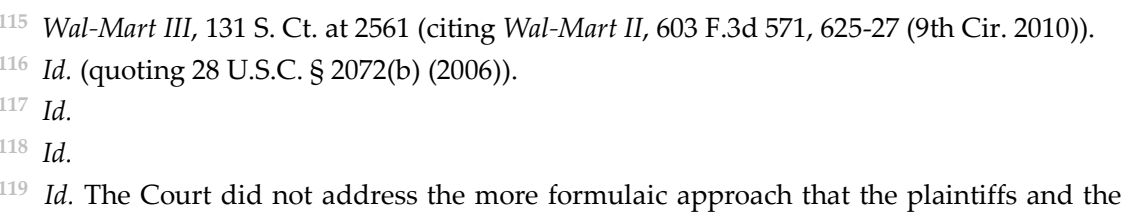

19 Id. The Court did not address the more formulaic approach that the plaintiffs and the district court had suggested based on Domingo v. New England Fish Co., 727 F.2d 1429, 1444 (9th Cir. 1984). The Domingo approach takes individualized data about every person in the class and calculates individualized damages based on objective data. Id. In contrast, the sampling approach disapproved by the Court takes a subset of members of the class and tries damages for them, then applies the results of those trials to other class members. Wal-Mart III, 131 S. Ct. at 2561.

120 See, e.g., Baby Neal ex rel. Kanter v. Casey, 43 F.3d 48, 56 (3d Cir. 1994) (citations omitted) ("The commonality requirement will be satisfied if the named plaintiffs share at least one question of fact or law with the grievances of the prospective class. . . Because the [commonality] requirement may be satisfied by a single common issue, it is easily met...."); Jenkins v. Raymark Indus., 782 F.2d 468, 472 (5th Cir. 1986) ("The threshold of 'commonality' is not high."); 1 AlBA CONTE \& HERBERT B. NEWBERG, NEWBERG ON ClASS ACTIONS § 3:10, at 274-77 \& n.9 (4th ed. 2002) (explaining commonality "is easily met in most cases"). 
promotions policies gave rise to unlawful discrimination."121 In her dissent, Justice Ginsburg agreed that this question was sufficient to establish "commonality" based on extensive evidence presented by Plaintiffs "that gender bias suffused Wal-Mart's company culture."122

A majority of the Court disagreed, holding that Plaintiffs had failed to establish sufficient commonality under Rule 23(a)(2). ${ }^{123}$ Justice Scalia wrote that "Rule 23 does not set forth a mere pleading standard" 124 but requires a "rigorous analysis" to ensure that the prerequisites of Rule 23(a) have been satisfied. ${ }^{25}$ This frequently "will entail some overlap with the merits of the plaintiff's underlying claim."126 In particular, "proof of commonality necessarily overlaps with" the merits in a case alleging a "pattern or practice of discrimination."127 The Court explained that the interrelationship between the merits and commonality existed "because, in resolving an individual's Title VII claim, the crux of the inquiry is 'the reason for a particular employment decision.'"'128

In other words, the majority held that the very nature of a pattern-orpractice Title VII claim requires a more rigorous commonality inquiry. Plaintiffs must not simply show common questions, but common answers to those questions. ${ }^{129}$ Justice Scalia wrote:

[Plaintiffs] wish to sue about literally millions of employment decisions at once. Without some glue holding the alleged reasons for all those decisions together, it will be impossible to say that examination of all the class members' claims for relief will produce a common answer to the crucial question why was I disfavored. ${ }^{130}$

As Wal-Mart had urged in its brief, the Court adopted a phrase from a footnote in General Telephone Co. of Southwest v. Falcon ${ }^{131}$ as the standard for

1 Wal-Mart III, 131 S. Ct. at 2564 (Ginsburg, J., dissenting).

122 Id. at 2563.

123 Id. at 2556-57 (majority opinion).

${ }^{124} I d$. at 2551 .

125 Id. (quoting Gen. Tel. Co. of Sw. v. Falcon, 457 U.S. 147, 161 (1982)).

126 Id.

127 Wal-Mart III, 131 S. Ct. at 2552 (emphasis in original).

${ }^{128}$ Id. (quoting Cooper v. Fed. Reserve Bank of Richmond, 467 U.S. 867, 876 (1984)).

129 See id. at 2551 (quoting Richard A. Nagareda, Class Certification in the Age of Aggregate Proof, 84 N.Y.U. L. REV. 97, 132 (2009)).

130 Id. at 2552.

131457 U.S. 147 (1982). In Falcon, a Mexican-American employee alleged that his employer did not promote him because of his race. Id. at 149. He sought class certification of MexicanAmerican applicants who had applied for employment with the defendant but who were not hired. Id. at 151 . Without an evidentiary hearing, the district court certified a class of both Mexican-American employees and applicants who had not been hired. Id. at 152. The Court 
commonality: Plaintiffs must show that the employer "used a biased testing procedure" or advance "[s]ignificant proof that an employer operated under a general policy of discrimination."132 The Court held that Plaintiffs could not show Wal-Mart used a "biased testing procedure" because "Wal-Mart has no testing procedure or other company-wide evaluation method that can be charged with bias."133

Plaintiffs argued that Wal-Mart's uniform policy of permitting excessive managerial discretion over pay and promotions-when the company knew it was having a discriminatory effect on female employees - was an employment policy and practice sufficient to establish commonality. The majority rejected the notion that Wal-Mart's subjective decision-making process could establish commonality, stating: "On its face, of course, that is just the opposite of a uniform employment practice that would provide the commonality needed for a class action; it is a policy against having uniform employment practices." 134 The Court blessed discretionary personnel systems as "a very common and presumptively reasonable way of doing business - one that we have said should itself raise no inference of discriminatory conduct." 135

The majority recognized that a system of unchecked discretion can establish Title VII disparate impact liability because "an employer's undisciplined system of subjective decision making [can have] precisely the same effects as a system pervaded by impermissible intentional discrimination." 136 But the Court found that using a policy of discretionary

held that the plaintiff had failed to show sufficient commonality between his failure-topromote claim and the potential claims of applicants who were not hired. Id. at 158. In a footnote, Justice Stevens wrote:

If [the employer had] used a biased testing procedure to evaluate both applicants for employment and incumbent employees, a class action on behalf of every applicant or employee who might have been prejudiced by the test clearly would satisfy the commonality and typicality requirements of Rule 23(a). Significant proof that an employer operated under a general policy of discrimination conceivably could justify a class of both applicants and employees if the discrimination manifested itself in hiring and promotion practices in the same general fashion, such as through entirely subjective decisionmaking processes.

Id. at $159 \mathrm{n} .15$ (emphasis added).

132 Wal-Mart III, 131 S. Ct. at 2553 (quoting Falcon, 457 U.S. at 159 n.15) (internal quotation marks omitted).

133 Id.

134 Id. at 2554

135 Id. (quoting Watson v. Fort Worth Bank \& Trust, 487 U.S. 977, 990 (1988)) (internal quotation marks omitted).

${ }^{136}$ Id. (quoting Watson, 487 U.S. at 990-91) (internal quotation marks omitted). 
decision making to unite a class was internally inconsistent. ${ }^{137}$ The majority presumed that "left to their own devices most managers in any corporation-and surely most managers in a corporation that forbids sex discrimination-would select sex-neutral, performance-based criteria for hiring and promotion that produce no actionable disparity at all."138 Even if other managers relied on criteria that caused a disparate impact, and others intentionally discriminated, the Court held that "demonstrating the invalidity of one manager's use of discretion will do nothing to demonstrate the invalidity of another's." 139 Therefore, "[a] party seeking to certify a nationwide class will be unable to show that all the employees' Title VII claims will in fact depend on the answers to common questions." 140

In essence, the majority in Wal-Mart implicitly imported the intent requirement from Title VII disparate treatment theory into the commonality requirement of Rule 23. Even if the policy of discretion adversely impacted women, the Court stated that Plaintiffs needed to identify "a common mode of exercising discretion that pervade[d] the entire company ...." 141 The Court tied this back to intentionality, finding that "[i]n a company of Wal-Mart's size and geographical scope, it is quite unbelievable that all managers would exercise their discretion in a common way without some common direction."142 In other words, the Court rejected disparate impact because it was not convinced that a policy of allowing discretion - at least on the nationwide level in a company of Wal-Mart's size-was really a "policy" in the same sense as policies challenged in other disparate impact cases, such as a test or objective job criterion, like minimum height or weight standards. ${ }^{143}$ Moreover, even if it was a common policy, every manager would likely exercise discretion

137 Id.

138 Wal-Mart III, 131 S. Ct. at 2554. The majority glaringly (but probably unconsciously) left out "compensation" decisions from its statement that most managers "would select sexneutral, performance-based criteria for hiring and promotion that produce no actionable disparity at all." See id. Indeed, compensation decisions that are unguided by job-related, performance-based criteria typically result in a greater gender wage gap. See infra Part III.A.

139 Wal-Mart III, 131 S. Ct. at 2554.

140 Id.

141 Id. at 2554-55.

142 Id. at 2555.

143 For examples of types of objective policies that have been challenged under disparate impact theory, see Dothard v. Rawlinson, 433 U.S. 321, 328-29 (1977) (challenging minimum height and weight requirements as causing disparate impact against women) and Griggs v. Duke Power Co., 401 U.S. 424, 425-26 (1971) (challenging requirement of high school education or passage of standardized general intelligence test as discriminatory condition of employment). 
differently under the policy, thereby defeating commonality for a patternor-practice claim.

And what about Plaintiffs' evidence that Wal-Mart's system of excessive, unchecked discretion led to stark pay disparities between men and women who performed equal work? The majority concluded that "[m]erely showing that Wal-Mart's policy of discretion has produced an overall sex-based disparity does not suffice."144 Plaintiffs must identify a "'specific employment practice' ... that ties all their 1.5 million claims together." 145

The Court criticized Dr. Bielby's expert testimony that Wal-Mart's system of discretionary decision making and "strong corporate culture" made it "'vulnerable' to 'gender bias.'"146 The Court pointed out that "Dr. Bielby conceded that he could not calculate whether 0.5 percent or 95 percent of the employment decisions at Wal-Mart might be determined by stereotyped thinking." 147 The Court suggested that Dr. Bielby's testimony might not satisfy the standards for expert testimony ${ }^{148}$ and noted that his conclusions in the case had "elicited criticism from the very scholars on whose conclusions he relie[d] for his social-framework analysis."149 Because Dr. Bielby could not specify how many employment decisions were affected by stereotypes, Justice Scalia wrote, "we can safely disregard what he has to say. It is worlds away from significant proof that Wal-Mart operated under a general policy of discrimination."150

The Court also found Plaintiffs' anecdotal evidence of sex-based comments "too weak to raise any inference that all the individual, discretionary personnel decisions are discriminatory."151 Although the Court proclaimed that it was not adopting a rule that anecdotes must be supplied in proportion to the size of the class, ${ }^{152}$ it noted that Plaintiffs' 120 declarations of discrimination represented "about 1 for every 12,500 class members-relating to only some 235 out of Wal-Mart's 3,400 stores."153 In

144 Wal-Mart III, 131 S. Ct. at 2556.

145 Id. at 2555-56.

146 See id. at 2553 (quoting Wal-Mart I, 222 F.R.D. 137, 152, 154 (N.D. Cal. 2004)).

147 Id. (quoting Wal-Mart I, 222 F.R.D. at 192) (internal quotation marks omitted).

148 The district court held that the standards for expert testimony under Daubert $v$. Merrell Dow Pharm., Inc., 509 U.S. 579 (1993), did not apply at the class-certification stage. Wal-Mart I, 222 F.R.D. at 191. The Court's "doubt" that Daubert does not apply at the class-certification stage, Wal-Mart III, $131 \mathrm{~S}$. Ct. at 2554, will likely cause trial courts to require expert testimony at the class certification stage to satisfy Daubert.

149 Wal-Mart III, 131 S. Ct. at 2553 n.8.

$150 I d$. at 2554 (internal quotation marks omitted).

151 Id. at 2556.

152 Id. at 2556 n.9.

153 Id. at 2556 (citing Wal-Mart II, 603 F.3d 571, 634 (9th Cir. 2010) (Ikuta, J., dissenting)). 
sum, "because [Plaintiffs] provide[d] no convincing proof of a companywide discriminatory pay and promotion policy, [the Court] concluded that they have not established the existence of any common question."154 Plaintiffs therefore could not proceed as a class.

As Judge Ginsburg expressed in her dissent, it is difficult to square the Court's ruling with its prior decision in Watson v. Fort Worth Bank $\mathcal{E}$ Trust, which "held that 'discretionary employment practices' can give rise to Title VII claims, not only when such practices are motivated by discriminatory intent but also when they produce discriminatory results."155 Watson explicitly stated that an employer's "undisciplined system of subjective decision making was an employment practic[e] that may be analyzed under the disparate impact approach." 156 Judge Ginsburg concluded that " $[t]$ he evidence reviewed by the District Court adequately demonstrated that resolving those claims would necessitate examination of particular policies and practices alleged to affect, adversely and globally, women employed at Wal-Mart's stores," and the commonality requirement in Rule 23(a)(2) "demands nothing further."157

Perhaps the majority's bastardization of Watson and heightened focus on the dissimilarities among plaintiffs working in many stores across the nation boils down to the Court's perception that mega-class actions are too unwieldy for employers to defend. Of course, plaintiffs are likely to simply split their class down into smaller cases to ensure they are linked more myopically by region, store, or manager. Breaking the case into bite-sized bits should address the majority's commonality concerns. But having multiple class actions involving the same employment practice will undermine judicial economy, raise litigation costs for all involved, and lead to the risk of inconsistent verdicts. Indeed, such concerns motivated the creation of Rule 23.

Aside from the impact that Wal-Mart will have on class action practice, the majority's opinion is riddled with dicta that reflects implicit hostility to pay-discrimination claims more generally. Despite Plaintiffs' rich statistical evidence of dramatic gender pay disparities, and examples of explicit sex bias by some managers, the majority simply could not believe that WalMart discriminated so profoundly and pervasively, at least not in a way that was common to a national class. The next Part explores what Wal-Mart teaches us about the legal quest for equal pay.

${ }^{154} I d$. at $2556-57$.

155 Wal-Mart III, 131 S. Ct. at 2564-65 (Ginsburg, J., dissenting) (citing Watson v. Fort Worth Bank \& Trust, 487 U.S. 977, 988, 991 (1988)).

${ }^{156} I d$. at 2565 (quoting Watson, 487 U.S. at 990-91) (internal quotation marks omitted).

157 Id. 


\section{Lessons for the Legal Quest for Equal Pay}

The Wal-Mart case demonstrates the uphill battle that plaintiffs often have in proving pay discrimination. In response to the Wal-Mart decision, some have called for legislative action. ${ }^{158}$ Congress has held hearings and efforts have been renewed to pass the Paycheck Fairness Act to ensure that women have an effective remedy to attack unequal pay for equal work. ${ }^{159}$ But what should that remedy be?

The implicit narrative underlying the majority's opinion in Wal-Mart should be mined carefully before more litigation remedies are thrown at the very real problem of gender-based pay disparities. Policymakers should understand how unjustified pay disparities are likely to occur and why current federal statutory remedies fail to address those disparities. The Wal-Mart case offers several insights into these questions.

\section{A. The Dynamics of Pay Discrimination in the Modern Workplace}

The first insight from Wal-Mart is the tension between Title VII's focus on intent-and the Court's emphasis on a "general policy of discrimination" for commonality - with the economic realities of how most pay discrimination happens in the modern workplace. The wages of employees today are more likely to be the product of discretionary or ambiguous pay regimes that do not have guiding criteria or, more importantly, sufficient corporate oversight or governing standards. ${ }^{160}$ In fact, the gender-wage gap is the largest for women whose wages are the product of individualized negotiation processes and greater discretion on the part of the employer, including those at the higher end of the occupational ladder-doctors, lawyers, and executives. ${ }^{161}$

158 See Beth Scott, Betty Dukes to U.S. Senate: The Best is Yet to Come!, AAUW DiALOG (June 30, 2011), http://blog-aauw.org/2011/06/30/betty-dukes-the-best-is-yet-to-come/ (noting that Wal-Mart "underscores the need to strengthen our federal employment discrimination laws through legislation like the Paycheck Fairness Act").

159 See Barriers to Justice and Accountability: How the Supreme Court's Recent Rulings Will Affect Corporate Behavior: Hearing Before the S. Comm. on the Judiciary, 112th Cong. (2011) [hereinafter Barriers to Justice and Accountability] (statement of Betty Dukes, Lead Plaintiff in Wal-Mart, Inc. v. Dukes), available at http://judiciary.senate.gov/pdf/11-6-29\%20Dukes\%20 Testimony.pdf.

160 Eisenberg, supra note 15, at 990 ("In the absence of a professional compensation survey, analyzed by a professional compensation consultant, 'market wages' are simply an employer's hunch about what the position is worth.").

161 See Bureau of Labor Statistics, U.S. Dep'T OF Labor, Highlights of WOMEN'S EARNINGS IN 2010, at 17 tbl.2 (2011) (representing that female physicians/surgeons earn $71 \%$ as much as their male counterparts); $i d$. at 15 tbl.2 (representing that female lawyers earn $77.1 \%$ as much as their male counterparts); $i d$. at $11 \mathrm{tbl} .2$ (representing that female chief executives earn $72.1 \%$ as much as their male counterparts). 
The evidence in Wal-Mart reflected this trend. Plaintiffs challenged a discretionary pay regime which led to dramatically different pay for men and women performing identical hourly, unskilled jobs. The amount of the pay gap increased for women in supervisory positions. For hourly workers and mid-level supervisors, women earned between $91 \%$ and $96 \%$ as much as men performing the same work. But, the gap widened dramatically at the top: Female Store Managers made only $84 \%$ as much as male Store Managers; female District Managers earned only $73 \%$ as much as their male counterparts; and female Regional Vice Presidents made only $67 \%$ as much. ${ }^{162}$

Extensive research shows that subjective, informal pay-setting processes often lead to pay disparities between men and women. ${ }^{163}$ For example, in a peer-reviewed management study, supervisors at a transportation company described female employees as experiencing greater family-work conflict than men, regardless of women's actual caregiving duties. This caused supervisors to view women's job fit, performance, and promotional opportunities more negatively. ${ }^{164}$ The researchers found a "motherhood wage penalty" of approximately $5 \%$ for one child and $7 \%$ for two or more children for female employees. ${ }^{165}$ In another study of the starting salaries of men and women leaving medical residency programs, that applied regression controls for multiple variables that could potentially affect wages, male physicians made on average $\$ 16,819$ more than female physicians. ${ }^{166}$

Justice Ginsburg, in her dissent, explained how discretionary pay regimes can facilitate pay disparities between men and women:

The practice of delegating to supervisors large discretion to make personnel decisions, uncontrolled by formal standards, has long been known to have the potential to produce disparate effects. Managers, like all humankind, may be prey to biases of which they are unaware. The risk of discrimination is heightened when those managers are predominantly of one sex, and are steeped in a corporate culture that perpetuates gender stereotypes. ${ }^{167}$

162 See Drogin Declaration, supra note 60, IIII 25-26, at 16 \& tbl.9.

163 See Eisenberg, supra note 15, at 971-82 (discussing statistics and multiple studies).

164 Sue Shellenbarger, The "Maternal Wall": Employer Bias Against Working Women, WALL ST. J., Dec. 3, 2009, available at http://blogs.wsj.com/juggle/2009/12/03/the-maternal-wall-employerbias-against-working-women/tab/print/.

165 See Deborah J. Anderson et al., The Motherhood Wage Penalty Revisited: Experience, Heterogeneity, Work Effort, and Work-Schedule Flexibility, 56 INDUS. \& LAB. REL. REV. 273, 273-76 (2003).

166 Anthony T. LoSasso et al., The \$16,819 Pay Gap for Newly Trained Physicians: The Unexplained Trend of Men Earning More than Women, 30 HeALth AfF. 193, 196 (2011).

167 Wal-Mart III, 131 S. Ct. 2541, 2564 (2011) (Ginsburg, J., dissenting) (footnote omitted). 
The majority conceded that discretionary pay systems can violate Title VII. At the same time, its dicta blessed such systems as a "very common and presumptively reasonable way of doing business." 168 The Court's opinion may have the unintended consequence of causing more pay inequities in American workplaces. Rather than developing pay regimes that are guided by job-related and objective criteria, companies may move to more subjective systems, with little centralized oversight, to avoid Title VII liability for pay disparities. ${ }^{169}$ This would not be a wise human resources strategy for other reasons: It can lower employee morale and productivity and, as explained below, could subject the employer to liability under the EPA, which does not permit subjective pay practices as defenses for pay disparities. Given that Wal-Mart is a market leader, however, many companies may follow its example of using discretionary pay regimes as a risk-management strategy. As Betty Dukes and the other women working at Wal-Mart can attest, this would be a disaster for the principle of equal pay for equal work.

\section{B. The Failure of Litigation Remedies to Address Structural Pay Discrimination}

\section{Title VII}

In addition to providing an example of the systemic and dramatic gender pay disparities that can result from excessively discretionary pay regimes, Wal-Mart shows the difficulty involved in challenging structural discrimination. Of course, the Court did not address the merits and was considering only whether "commonality" existed for class certification under Rule 23. Nevertheless, its decision that a common discriminatory employment policy did not exist was grounded in the "detailed remedial scheme" of Title VII itself, particularly for pattern-or-practice cases. ${ }^{170}$

\footnotetext{
168 Id. at 2554.

169 See Hart Testimony, supra note 9, at 3 ("By making class action litigation of employment discrimination claims less likely, the Wal-Mart decision also takes pressure off of employers to adopt the best internal practices for ensuring that workplace decisions are made fairly and without illegal stereotyping and bias.").

170 See Wal-Mart III, $131 \mathrm{~S}$. Ct. at 2552. In a pattern-or-practice case, the plaintiffs first "establish by a preponderance of the evidence that . . discrimination was the company's standard operating procedure[,] the regular rather than the unusual practice." Id. (quoting Int'1 Bhd. of Teamsters v. United States, 431 U.S. 324, 336 (1977)). That prima facie "showing will support a rebuttable inference that all class members were victims of the discriminatory practice, and will justify 'an award of prospective relief,' such as 'an injunctive order against the continuation of the discriminatory practice.'" Id. at 2552 n.7 (quoting Teamsters, 431 U.S. at 361).
} 
Many plaintiffs lose Title VII pay discrimination cases because most courts, like Justice Scalia and his brethren, presume the good faith of businesses. Courts typically resist interfering with any type of compensation decision - not only in the pay discrimination context, but also in the area of executive compensation. ${ }^{171}$ In a Title VII pay discrimination case, "smoking gun" evidence of sex-based animus is not required, ${ }^{172}$ but plaintiffs are more likely to win if they have it. ${ }^{173}$

Certainly, at least some of the managers at Wal-Mart articulated such sexist intentions. Plaintiffs reported that managers told them things like: "Men need to be paid more than women because they have families to support"; male employees would always make more because "God made Adam first, so women would always be second to men"; and "You don't have the right equipment.... [Y]ou aren't male, so you can't expect to be paid the same."174 When one plaintiff asked her manager why a male coworker in the same position was making $\$ 10,000$ more per year, the manager told her to bring in her household budget so he could decide whether she deserved as much as the man. ${ }^{175}$ The majority, however, could not accept the notion that all managers of the 1.5 million women in the class would likewise have the same discriminatory intent.

After Wal-Mart, a class of women alleging Title VII pattern-or-practice pay discrimination must provide "convincing proof of a companywide

\footnotetext{
171 Eisenberg, supra note 15, at 999-1000 (discussing reluctance of courts to interfere with compensation decisions in both executive compensation and pay discrimination cases); see also DeJarnette v. Corning, Inc., 133 F.3d 293, 299 (4th Cir. 1998) ("[T]his Court 'does not sit as a kind of super-personnel department weighing the prudence of employment decisions made by firms charged with employment discrimination ....'" (quoting Giannopoulous v. Brach \& Brock Confections, Inc., 109 F.3d 406, 410 (7th Cir. 1997))); Shealy v. City of Albany, 89 F.3d 804, 806 n.6 (11th Cir. 1996) ("The district judge does not sit as a sort of 'super personnel officer'" of the employer.).

172 Under Title VII's burden-shifting scheme, a plaintiff can establish a prima facie case of pay discrimination by showing that she is similarly situated to a male employee and receives less pay. The employer must then put forth a legitimate, non-discriminatory reason for the disparate pay. Title VII does not put the burden on the employer to prove that this was the actual reason for the unequal pay decision. After the employer offers a reason, the burden of persuasion then shifts back to the plaintiff to prove that the employer's purported justification was a mere "pretext" for discrimination and the real reason for the disparity was her sex. See Tex. Dep't of Cmty. Affairs v. Burdine, 450 U.S. 248, 254-55 (1981).

173 See, e.g., Brinkley-Obu v. Hughes Training, Inc., 36 F.3d 336, 340 (4th Cir. 1994) (employer told plaintiff to be an engineer or a "mama").

174 See generally Plaintiffs' Motion for Class Certification, supra note 69 (providing examples of sex-based explanations for pay disparities by Wal-Mart supervisors).

175 Barriers to Justice and Accountability, supra note 159, at 3-4, available at http://judiciary. senate.gov/pdf/11-6-29\%20Dukes\%20Testimony.pdf.
} 
discriminatory pay and promotion policy."176 That policy may not simply be a policy of discretion that has a discriminatory effect-it must be a "general policy of discrimination" in and of itself. ${ }^{177}$ The Court described Wal-Mart's policy of "allowing discretion by local supervisors over employment matters" as "just the opposite of a uniform employment practice that would provide the commonality needed for a class action; it is a policy against having uniform employment practices."178

The plaintiffs in Wal-Mart also alleged "disparate impact" under Title VII, which does not require a showing of intent. ${ }^{179}$ The Court had previously held that "an employer's undisciplined system of subjective decisionmaking [can have] precisely the same effects as a system pervaded by impermissible intentional discrimination."180 Although disparate impact sounds powerful in theory, it has been less potent in practice. ${ }^{181}$ Even before Wal-Mart, most plaintiffs lost disparate impact cases. ${ }^{182}$ By holding that the discretionary pay system at issue in Wal-Mart could not be a "general policy of discrimination" sufficient to establish commonality, the Court has raised the bar for class certification of disparate impact claims.

\section{Equal Pay Act}

If Betty Dukes and the women at Wal-Mart had filed an EPA claim instead of a Title VII pay discrimination claim, the result may have been different, at least for the pay claims. ${ }^{183}$ The EPA offers several conceptual

6 Wal-Mart III, 131 S. Ct. 2541, 2556 (2011).

Id. at 2553 (quoting Gen. Tel. Co. of Sw. v. Falcon, 457 U.S. 147, 159 n.15 (1982)).

178 Id. at 2554.

179 See, e.g., Griggs v. Duke Power Co., 401 U.S. 424, 431 (1971) ("The Act proscribes not only overt discrimination but also practices that are fair in form, but discriminatory in operation.").

180 Watson v. Fort Worth Bank \& Trust, 487 U.S. 977, 990-91 (1988).

181 Porter \& Vartanian, supra note 20, at 181 ("While some courts have addressed disparate impact claims alleging pay discrimination, there remains uncertainty as to whether a disparate impact claim is even cognizable for pay discrimination cases."); Elaine W. Shoben, Disparate Impact Theory in Employment Discrimination: What's Griggs Still Good For? What Not?, 42 BRANDEIS L.J. 597, 597 (2004) ("Despite the heroic effort of Congress to keep the theory from destruction by the Supreme Court through its express codification in 1991, disparate impact litigation is not making a major impact in this new century.").

182 Melissa Hart, Disparate Impact Discrimination: The Limits of Litigation, The Possibilities for Internal Compliance, 33 J.C. \& U.L. 547, 549 (2007) ("In the district courts, plaintiffs are successful in about 25 percent of disparate impact cases; in the courts of appeals, plaintiffs fare even worse, winning about 19 percent of the time on their disparate impact arguments." (citing Michael Selmi, Was the Disparate Impact Theory a Mistake?, 53 UCLA L. REV. 701, 738-39 (2006))).

183 The EPA only addresses pay disparities and not other types of employment actions. A significant portion of the plaintiffs' claims in Wal-Mart concerned failure-to-promote claims. 
advantages over Title VII as a remedy for disparate pay. "Intent" is irrelevant under the EPA. ${ }^{184}$ The plaintiff must first "show that an employer pays different wages to employees of opposite sexes 'for equal work on jobs the performance of which requires equal skill, effort, and responsibility, and which are performed under similar working conditions.'"'185 If the plaintiff makes this prima facie showing, the burden of proof "shifts to the employer to show that the differential is justified under one of the Act's four exceptions."186 Unlike Title VII, the employer must prove the actual reason for the pay disparity and cannot simply offer post hoc, theoretical explanations. ${ }^{187}$ In addition, unlike Title VII, the employer bears the ultimate burden of persuasion to prove the legality of the pay disparity under the EPA. Finally, unlike Title VII, subjective pay decisions are not acceptable defenses under the EPA.

It is not uncommon for plaintiffs to win EPA claims and lose Title VII pay discrimination claims. ${ }^{188}$ The EPA's framework is easier for juries and judges to accept. Like Justice Scalia, most people would prefer to believe that managers try to do the right thing and do not intend to discriminate against women. Nevertheless, where pay disparities between workers performing substantially equal jobs occur for whatever reason, and the

See Plaintiff's Motion for Class Certification and Memorandum of Points and Authorities at 28-29, Wal-Mart III, 131 S. Ct. 2541 (2011) (No. C-01-2252).

184 The EPA imposes "a form of strict liability on employers who pay males more than females for performing the same work-in other words, the plaintiff . . . need not prove that the employer acted with discriminatory intent." See Mickelson v. N.Y. Life Ins. Co., 460 F.3d 1304, 1310-11 (10th Cir. 2006).

185 Corning Glass Works v. Brennan, 417 U.S. 188, 195 (1974) (quoting 29 U.S.C. § 206(d)(1) (2006)).

186 Id. at 196. The EPA's affirmative defenses include: "(i) a seniority system; (ii) a merit system; (iii) a system which measures earnings by quantity or quality of production; or (iv) a differential based on any other factor other than sex." 29 U.S.C. $\$ 206(d)(1)$.

187 See, e.g., Stanziale v. Jargowsky, 200 F.3d 101, 108 (3d Cir. 2000) (citation omitted) ("Thus, unlike an ADEA or Title VII claim, where an employer need not prove that the proffered legitimate nondiscriminatory reasons actually motivated the salary decision ... in an Equal Pay Act claim, an employer must submit evidence from which a reasonable factfinder could conclude that the proffered reasons actually motivated the wage disparity.").

188 See, e.g., King v. Univ. Healthcare Sys., L.C., 645 F.3d 713, 724 (5th Cir. 2011) (explaining that it was not inconsistent for the jury to rule in favor of the plaintiff on the EPA claim, but not on the Title VII claim, because "where the defendant proffers a reason for its pay differential other than sex, but does not prove that reason by a preponderance of the evidence, the plaintiff will succeed on an EPA claim while still bearing the burden of persuasion under Title VII"); Fallon v. Illinois, 882 F.2d 1206, 1217 (7th Cir. 1989) ("It is possible that a plaintiff could fail to meet its burden of proving a Title VII violation, and at the same time the employer could fail to carry its burden of proving an affirmative defense under the Equal Pay Act."); Brewster v. Barnes, 788 F.2d 985, 987 (4th Cir. 1986) (holding defendant liable for pay discrimination under EPA but not under Title VII). 
employer cannot prove the imbalance is justified by reasonable businessrelated reasons, the EPA requires that the employer correct the problem.

Although the EPA offers a more streamlined litigation model, most modern-day plaintiffs lose EPA claims for two major reasons. First, the EPA's "equal work" prima facie standard is more difficult for most women to satisfy. As our economy moves away from standardized manufacturing jobs to more flexible, fluid working arrangements, proving that two jobs are "equal" has become a huge hurdle for most EPA plaintiffs. Women in upper-level jobs - for whom the pay gap tends to be the largest-typically cannot satisfy the EPA's prima facie standard, which was developed for lower-wage, assembly-line workers. An empirical study of EPA cases since the Act's passage found that employees are less likely to prevail on equal pay claims today than during any other decade. ${ }^{189}$ In addition, from 19992009 federal district courts granted summary judgment to the employer $72 \%$ of the time. ${ }^{190}$ Of course, for women working at Wal-Mart, the prima facie standard under the EPA should be relatively easy to satisfy because Wal-Mart's positions are so standardized. There is little to no difference in the "skill, responsibility, and effort" that would distinguish one greeter, cashier, or store manager from another. ${ }^{191}$ But for most jobs in the modern economy, cookie-cutter identity is rare and a more pragmatic prima facie standard is needed.

The other stumbling block for many EPA plaintiffs is the catch-all "factor-other-than-sex" defense. This has increasingly become a loophole under which employers may justify pay decisions. A majority of federal circuits and the Equal Employment Opportunity Commission have held that this defense must be job-related and adopted for a legitimate business reason. ${ }^{192}$ But some circuits have held that the factor-other-than-sex defense

189 See Eisenberg, supra note 29, at 33 tbl.1 (showing that employees prevailed on EPA claims in federal courts of appeal cases $35 \%$ of the time from $2000-2009$, as compared to $55 \%$ from $1990-1999,52 \%$ between $1980-1989$, and $59 \%$ between 1970-1979). The author is updating this research for a symposium about the overuse of summary judgment in employment cases in April 2012 at New York Law School, the results of which will be published in the New York Law Review.

190 Id. at 34.

191 Of course, Wal-Mart would likely argue that different departments mean different jobs, but that defense has typically been rejected by courts in cases involving lower-wage hourly workers. See, e.g., EEOC v. Shelby Cnty., 707 F. Supp. 969, 983 (W.D. Tenn. 1988) (holding that a cashier and exhibit custodian were comparable despite differences in duties because "there is little difference between the degree of responsibility required"); Usery v. Johnson, $436 \mathrm{~F}$. Supp. 35, 38-42 (D.N.D. 1977) (holding sales clerks in different departments equal); Brennan v. Sears, Roebuck \& Co., 410 F. Supp. 84, 95 (D. Iowa 1976) (holding that division managers performed equal work).

192 See Steger v. Gen. Elec. Co., 318 F.3d 1066, 1078-79 (11th Cir. 2003) (internal quotation 
can be any reason at all. ${ }^{193}$ Vague defenses based on "market forces" have been increasingly accepted by some courts, even though such defenses are not acceptable under the EPA.

\section{Blueprint for an Effective Legal Remedy for Unequal Pay}

The Wal-Mart case highlights the Catch-22 that women face in trying to address unjustified pay disparities in the workplace. They cannot challenge discretionary pay regimes under Title VII because they typically lack evidence of intentional discrimination. ${ }^{194}$ After Wal-Mart, they will have a

marks ommitted) ("Because the evidence showed that the salary retention plan was justified by special exigent circumstances connected with the business, . . . and because there was no evidence which rebutted GE's explanation, the district court did not err in submitting the matter to the jury or in denying Steger's motion for judgment as a matter of law." (quoting Irby v. Bittick, 44 F.3d 949, 955 (11th Cir. 1995))); Belfi v. Prendergast, 191 F.3d 129, 136 (2d Cir. 1999) ("[T]o successfully establish the 'factor other than sex' defense, an employer must also demonstrate that it had a legitimate business reason for implementing the gender-neutral factor that brought about the wage differential."); Aldrich v. Randolph Cent. Sch. Dist., 963 F.2d 520, 526 (2d Cir. 1992) ("[A]n employer bears the burden of proving that a bona fide business-related reason exists for using the gender-neutral factor that results in a wage differential in order to establish the factor-other-than-sex defense."); EEOC v. J.C. Penney Co., 843 F.2d 249, 253 (6th Cir. 1988) ("[T]he 'factor other than sex' defense does not include literally any other factor, but a factor that, at a minimum, was adopted for a legitimate business reason."); Glenn v. Gen. Motors Corp., 841 F.2d 1567, 1571 (11th Cir. 1988) ("[T]he 'factor-other-than-sex' exception applies when the disparity results from unique characteristics of the same job; from an individual's experience, training, or ability; or from special exigent circumstances connected with the business."); Kouba v. Allstate Ins. Co., 691 F.2d 873, 876 (9th Cir. 1982) ("The Equal Pay Act concerns business practices. It would be nonsensical to sanction the use of a factor that rests on some consideration unrelated to business. An employer thus cannot use a factor which causes a wage differential between male and female employees absent an acceptable business reason."); EEOC, Directives Transmittal No. 915.003, § 10.IV.F.2 \& nn.65-66 (Dec. 5, 2000), available at http://www.eeoc.gov/policy/docs/compensation.html\#N_65 ("An employer . . . must show that the factor is related to job requirements or otherwise is beneficial to the employer's business [and] the factor must be used reasonably in light of the employer's stated business purpose as well as its other practices.").

193 See Taylor v. White, 321 F.3d 710, 719 (8th Cir. 2003) ("In conducting this examination, our concern is not related to the wisdom or reasonableness of the asserted defense. It is related solely to the issue of whether the asserted defense is based on a factor other than sex."); Dey v. Colt Constr. \& Dev. Co., 28 F.3d 1446, 1462 (7th Cir. 1994) ("[T]he EPA's fourth affirmative defense is a broad catch-all exception [that] embraces an almost limitless number of factors, so long as they do not involve sex.... The factor need not be related to the requirements of the particular position in question, nor must it even be business-related." (citations omitted) (internal quotation marks omitted)).

194 See Parada v. Great Plains Int'l of Sioux City, Inc., 483 F. Supp. 2d 777, 791 (N.D. Iowa 2007) ("Employment discrimination and retaliation, except in the rarest cases, is difficult to prove. It is perhaps more difficult to prove such cases today than during the early evolution of 
more difficult time banding together with coworkers to challenge discretionary pay structures that have a disparate impact on female employees without convincing proof that the discretion was exercised in a common way. And if they sue under the EPA, they are likely to lose because of either the strict prima facie standard or the catch-all "factorother-than-sex" defense.

To contribute to the discussion about whether and how policymakers should respond to the Wal-Mart decision, this section proposes modified legal approaches to discourage pay discrimination that may be more effective and consistent with compensation practices in the modern-day workplace.

\section{Incentives for Self-Regulation by Employers}

The most effective way to eliminate unjustified pay disparities, of course, is to convince employers to take proactive steps to eliminate them. As argued in previous work, litigation tends to be an ineffective way to address pay discrimination because litigation is reactive (by the time a woman discovers a disparity, it has grown for years or decades), piecemeal (even more so now that large classes of women will have more difficulty joining together to challenge structural pay discrimination), and typically unsuccessful (most plaintiffs lose their cases at the summary judgment stage) ${ }^{195}$ The ultimate goal of statutory regimes like Title VII is to promote voluntary remedial efforts by employers, not to encourage more litigation. ${ }^{196}$ The Wal-Mart decision portends the opposite. With the Court's blessing of discretionary pay regimes as reasonable and virtually immune from large-scale Title VII challenge, employers lack incentives to change them. Indeed, employers may move to more discretionary pay regimes as a shield against potential Title VII liability.

One way to convince employers to take pay disparities seriously would be to require pay transparency in the workplace. ${ }^{197}$ This is not as radical as it may sound. Some employers already have adopted an "openbook" management structure, which, they report, has cultivated greater

federal and state anti-discrimination and anti-retaliation laws. Today's employers, even those with only a scintilla of sophistication, will neither admit discriminatory or retaliatory intent, nor leave a well-developed trail demonstrating it.").

195 See Eisenberg, supra note 15, at 970-71.

196 See Ford Motor Co. v. EEOC, 458 U.S. 219, 228 (1982) ("To accomplish this objective [of bringing employment discrimination to an end], the legal rules fashioned to implement Title VII should be designed, consistent with other Title VII policies, to encourage Title VII defendants promptly to make curative, unconditional job offers to Title VII claimants, thereby bringing defendants into 'voluntary compliance' and ending discrimination far more quickly than could litigation ....").

197 See Eisenberg, supra note 15, at 958. 
loyalty and productivity among employees. ${ }^{198}$ For decades, mandated disclosure has been used to regulate executive compensation. The underlying theory of such disclosure is that transparency will weed out underlying cognitive and social factors that can, consciously or unconsciously, lead to abusive pay. ${ }^{199}$ Executive compensation scholars have explained how the human dynamics and conditions involved in pay negotiations can lead to pay abuses, particularly if conducted in secret. They have shown the ineffectiveness of litigation to fully address the problem because of court reluctance to interfere with "business judgments" about pay. And they have urged the crucial role of transparency-that is, exposing pay arrangements to the disinfecting power of "sunshine" - to force companies to ensure that their pay arrangements can be reasonably justified based on the requirements of the job and the performance of the executive. ${ }^{200}$

The regulatory approach to pay discrimination should be more similar, at least on a conceptual level, to that of executive compensation. ${ }^{201}$ Rather than portraying pay discrimination as the result of employers' intentional victimization of women, it should be conceptualized as a market failure. ${ }^{202}$ This market failure is caused by asymmetric information when wages are established through secret, unchecked discretionary pay regimes or negotiation processes. Adequate, accurate information is a crucial component of any effectively functioning market. Yet, most people know more about the consumer products they buy than they do about their own market value. Transparent pay systems would encourage employers to develop and explain to employees the criteria on which compensation is based, and to ensure that they can justify pay disparities. Transparency would help employees, and women in particular, have a better sense of their value and help them to negotiate for fair wages. Pay transparency would serve as an "outrage constraint" on unjustified pay. Employers would be more careful to ensure that the wage offered was consistent with the "skill, effort, and responsibility" of the job and that any pay disparities between employees performing substantially similar jobs can be explained by job-related or business-related reasons ${ }^{203}-$ like the EPA requires.

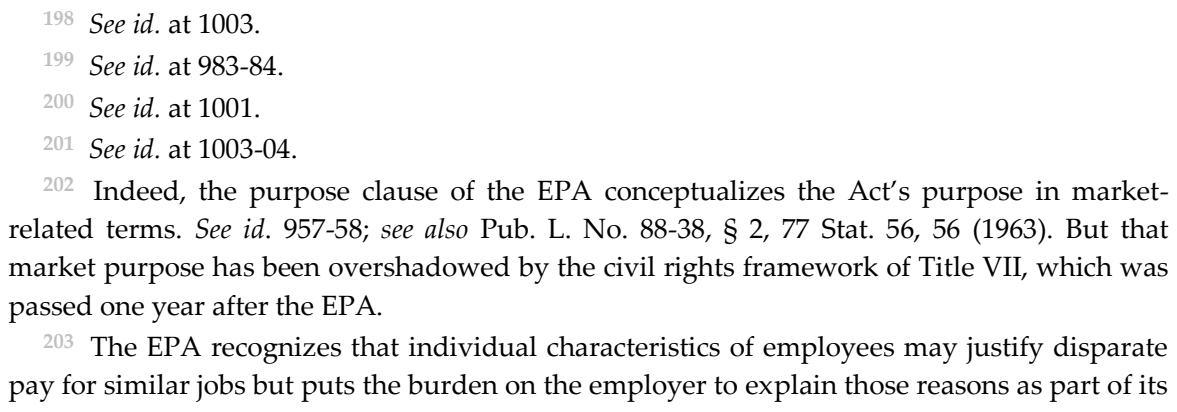

203 The EPA recognizes that individual characteristics of employees may justify disparate pay for similar jobs but puts the burden on the employer to explain those reasons as part of its 
Of course, transparency alone will not work without providing employers with an incentive to control for and correct unjustified pay disparities between employees performing similar work. One approach would be to require employers of a certain size to conduct periodic compensation audits to detect pay disparities between men and women performing similar jobs. These audits would help to identify and correct any disparities between employees performing the same work that arose from inadvertence, unconscious biases, or a host of other social or cognitive factors that may not rise to the level of intentional discrimination. For any pay disparity between employees performing similar work that exceeded a certain threshold, the employer would have to either make adjustments for the lower-paid employee or document the reasons for the disparities. Some employers, such as IBM, already follow this annual auditing practice. ${ }^{204}$ Although employers should not be required to submit the reports to the government, they should be required to keep them for the same period of time that they are required to maintain payroll records under federal law. The records should be available for random audits by the Department of Labor, which already conducts periodic audits for overtime and minimum wage violations. If the employer fails to conduct or maintain adequate records of its pay audits, the investigating agency should be able to impose fines for non-compliance. In addition, in the absence of adequate recordkeeping, the employer should forfeit certain affirmative defenses, such as the "factor-other-than-sex" affirmative defense under the EPA. 205

Requiring pay transparency or periodic compensation audits would provide powerful incentives for employers to be more thoughtful and defined about their compensation plans. Rather than investing individual managers with unchecked, excessive discretion that can cause unjustified pay disparities against women, employers would be forced to articulate reasonable, job-related criteria for pay awards and pay attention to internal pay equity concerns. Employers would maintain flexibility to vary wages for reasons such as experience, qualifications, performance, greater responsibility, and other factors that are related to the job in question. But employers would be unable to sustain wholly discretionary, ill-defined pay schemes that systematically and consistently disadvantage women

affirmative defense. See 29 U.S.C. § 206(d)(1) (2006)

204 Lisa A. Mainiero \& Sherry E. Sullivan, The Opt-Out Revolt: Why People Are LEAVING CoMPANIES to CREATE KALEIDOSCOPE CAREERS 286 (2006).

205 Professor Gowri Ramachandran likewise proposes that pay transparency be an affirmative defense to pay discrimination claims. Gowri Ramachandran, Pay Transparency, 116 PENN ST. L. ReV. (forthcoming 2012) (manuscript at 4) ("I propose a new kind of intervention into discrimination through pay transparency-one that leverages the financial interest of employers and employees."). 
workers.

The Paycheck Fairness Act ("PFA")206 pending in Congress takes baby steps in the direction of pay transparency. The Act prohibits an employer from retaliating against any employee who "has inquired about, discussed, or disclosed the wages of the employee or another employee." 207 The Act instructs the Department of Labor to "conduct studies and provide information to employers, labor organizations, and the general public concerning the means available to eliminate pay disparities between men and women...."208 The Act also authorizes the Equal Employment Opportunity Council ("EEOC") to complete a survey of pay data that is currently available under federal law and then "issue regulations to provide for the collection of pay information data from employers as described by the sex, race, and national origin of employees." 209

These anti-retaliation and data collection provisions may not be a panacea, but they would force employers to address pay disparities among employees who perform similar jobs before a lawsuit is filed. As scholars have recognized in explaining the benefit of pay disclosure in the executive compensation context, "[t]his is an area in which the very recognition of problems may help to alleviate them. Managers' ability to influence pay structures depends on the extent to which the resulting distortions are not too apparent to market participants ...." ${ }^{210}$

\section{A More Workable Litigation Remedy}

Although voluntary efforts by employers to correct unjustified pay disparities are preferable to litigation for both employers and employees, a statutory remedy for pay discrimination remains crucial as an incentive for employer compliance and a means of employee redress. As Professor Melissa Hart has written: "Without the possibility of redressing harm, ... the likelihood of avoiding harm is substantially diminished." 211 A more effective legal remedy for pay discrimination would build on the existing conceptual framework of the EPA, but modify the statute to make it compatible with the dynamics that can cause gender pay disparities. The PFA, if modified, would be a step in the right direction. ${ }^{212}$

206 H.R. 1519, 112th Cong. (2011).

207 Id. $\S 3(\mathrm{~b})(1)(\mathrm{B})$.

208 Id. $\S 6$.

209 Id. $\S 8$.

210 Lucian Bebchuk \& Jesse Fried, Pay Without Performance: The Unfulfilled PROMISE OF EXECUTIVE PAY 12 (2004).

211 Hart Testimony, supra note 9, at 6.

212 Other scholars have explained how passage of the Paycheck Fairness Act ("PFA") would help to eliminate market defenses in equal-pay litigation. See Martha Chamallas, 


\section{a. The "Bona-Fide-Factor-Other-Than-Sex" Affirmative Defense}

The most important provision in the PFA would tighten the "factorother-than-sex" affirmative defense. As explained in prior scholarship, this defense has become a broad market excuse that has immunized employers from EPA liability in some circuits. ${ }^{213}$ If interpreted consistently with the original purpose of the EPA, the "factor-other-than-sex" defense should be limited to those defenses that are job-related and consistent with business necessity, as a majority of circuits and the EEOC have held.

The PFA codifies the majority approach by replacing the vague phrase "any other factor other than sex" with the more specific terms "a bona fide factor other than sex, such as education, training, or experience." 214 The Act also clarifies that the "bona fide factor defense" applies "only if the employer demonstrates that such factor (i) is not based upon or derived from a sex-based differential in compensation; (ii) is job-related with respect to the position in question; and (iii) is consistent with business necessity." 215 If the employer satisfies this standard of proof, the employee then has the opportunity to demonstrate "that an alternative employment practice exists that would serve the same business purpose without producing such differential and that the employer has refused to adopt

Ledbetter, Gender Equity and Institutional Context, 70 OHIO ST. L.J. 1037, 1051 (2009) (“[T]he PFA is not the broad stroke that anyone seriously contends will be sufficient to close the gender pay gap. If passed on the heels of Ledbetter, however, it would constitute a significant ripple effect that goes well beyond the highly technical point of law in Lilly Ledbetter's case."); Porter \& Vartanian, supra note 20, at 197-98, 203 (explaining that the Paycheck Fairness Act may help to end the pay gap by minimizing the use of market excuses in equal-pay cases, but suggesting that the compensatory and punitive damages provision in the Act be eliminated to ensure passage); Sharon Rabin-Margalioth, The Market Defense, 12 U. PA. J. Bus. L. 807, 810 (2010) ("If this important legislation becomes law, the market defense will be eliminated altogether from the EPA framework of discrimination."). But see June E. O'Neill, Op-Ed., Washington's Equal Pay Obsession, WALl ST. J., Nov. 16, 2010, at A19 ("[T] he PFA is not fair, sensible or warranted, and it will impose great costs on employers. Some firms undoubtedly discriminate against women, but their number is small and the federal government's existing antidiscrimination apparatus is more than adequate. This new legislation would simply provide a feast for lawyers-and, by increasing the cost of employing women, would likely harm its intended beneficiaries."); Christina Hoff Sommers, Op-Ed., Fair Pay Isn't Always Equal Pay, N.Y. TIMES, Sept. 21, 2010, available at http://www.nytimes.com/2010/09/22/opinion/22Sommers.html ("[The bill] overlooks mountains of research showing that discrimination plays little role in pay disparities between men and women, and it threatens to impose onerous requirements on employers to correct gaps over which they have little control.").

213 See Eisenberg, supra note 29, at 59-61.

214 Paycheck Fairness Act, H.R. 1519, 112th Cong. § 3(a)(2) (2011).

${ }^{215}$ Id. $\S 3(\mathrm{a})(3)(\mathrm{B})$. 
such alternative practice." 216 Passage of the "bona fide factor" provision would ensure that pay disparities are justified by skill, responsibility, and effort required for the position, and the unique qualifications and merit of the employee filling that position. ${ }^{217}$

\section{b. A Pragmatic Prima Facie Standard for Similar Work}

One problem left unaddressed by the PFA, as currently drafted, is the prima facie standard of "equal work." Some courts interpret this standard so strictly that it imposes a glass ceiling on the EPA by excluding women in non-standardized jobs from its coverage. ${ }^{218}$ Consequently, changing the affirmative defenses in the EPA will not help plaintiffs who cannot overcome the preliminary prima facie hurdle. It is comparable to the "qualified individual with a disability" threshold under the Americans with Disabilities Act ("ADA"), which federal courts once interpreted so restrictively that many ADA cases were dismissed at the prima facie stage without any consideration of the merits of the claim. ${ }^{219}$ Congress ultimately clarified the broad scope of the ADA's protections. ${ }^{220}$

Congress should likewise clarify that the EPA demands a more pragmatic interpretation that does not mandate strict identity among compared jobs. Alternatively, the prima facie standard could be changed to either a "similarly situated" standard-like that under Title VII-or a "comparable work" standard, as proposed in the original EPA221 and used in many state equal-pay laws. ${ }^{222}$ This should not be confused with "comparable worth," which focuses on the intrinsic value or worth of the job.223 In contrast, a "comparable work" or "similarly situated" prima facie standard would require the plaintiff to show that the predominant nature and duties of the work are substantially the same in terms of skill, responsibility, and effort, even if not identical in all respects. This would allow, for example, a female executive paid less than men on the executive team or employees performing similar work in different departments to satisfy the prima facie showing under the EPA.

\footnotetext{
${ }^{216} I d$.

217 See Porter \& Vartanian, supra note 20, at 197-202 (offering other explanations of the impact the "bona fide factor defense" would have on equal pay cases).

218 Eisenberg, supra note 29, at 39-41.

219 See generally Toyota Motor Mfg., Ky. v. Williams, 534 U.S. 184, 191-202 (2002).

220 ADA Amendments Act of 2008, Pub. L. No. 110-325, 122 Stat. 3553.

221 See Eisenberg, supra note 29, at 29 (citing CARL E. VAN HORN \& HERBERT A. SCHAFFNER, WORK IN AMERICA: AN ENCYCLOPEDIA OF HISTORY, POLICY, AND SOCIETY 187-88 (2003)).

222 Id. at $46-47$.

${ }^{223}$ Id. at 22 (quoting Cnty. of Wash. v. Gunther, 452 U.S. 161, 166 (1981)).
} 
At the same time, if flexibility is added to the prima facie standard, the EPA should be amended to allow for de minimis variations in pay. As currently written, the EPA requires precisely "equal pay" - down to the last penny. ${ }^{224}$ Allowing for de minimis differences would recognize the need for some employer flexibility and avoid quibbling over small amounts. The definition of de minimis could vary depending on the nature of the position but should be narrowly construed to avoid abuses. For hourly jobs in which the tasks are routinized and identical, variations should be minimal or nonexistent. For higher wage jobs, a higher de minimis variation - for example, $\$ 1000$ or less or some other threshold amount per year-should be allowed.

\section{c. Group Actions for Systemic Pay Discrimination}

The Wal-Mart case highlights one of the biggest problems for women who experience systemic pay discrimination resulting from discretionary pay systems: Women cannot challenge discretionary pay systems under Title VII in a large class action. The PFA would permit Rule 23 class actions under the EPA.225 After Wal-Mart, however, seeking Rule 23 class certification may not be successful, especially if the pay discrimination results - as it frequently does-from a discretionary or ambiguous pay scheme. One option would be to overturn Wal-Mart with a provision that clarifies that excessively discretionary, unchecked compensation schemes that result in disparate pay between men and women performing similar work constitute a general policy of discrimination sufficient to establish commonality under Rule 23 for Title VII and EPA claims.

Another option would be to modify the collective action procedure for the EPA. Because the EPA is part of the Fair Labor Standards Act ("FSLA"), class actions are not permitted. ${ }^{226}$ Under FLSA's collective action structure, every plaintiff must affirmatively "opt in" to the litigation by filing a signed consent form with the court. 227 The benefit of this approach is that the preliminary certification standard for a collective action is significantly more lenient than the standards for class certification. ${ }^{228}$ Plaintiffs only

224 Hodgson v. Am. Bank of Commerce, 447 F.2d 416, 420 (5th Cir. 1971) (“Any wage differential between the sexes, no matter how small and insignificant, is sufficient under the statutory prohibition.").

225 H.R. 1519, 112th Cong. §3(c)(3)-(4) (2011).

226 Equal Pay Act, 29 U.S.C. § 216(b) (2006).

227 Id. ("No employee shall be a party plaintiff to any such action unless he gives his consent in writing to become such a party and such consent is filed in the court in which such action is brought.").

228 See Cunningham v. Elec. Data Sys. Corp., 754 F. Supp. 2d 638, 643 (S.D.N.Y. 2010) (citations omitted) (internal quotations marks omitted) ("The similarly situated standard is far 
need to show that they are "similarly situated" and do not have to satisfy the more demanding prerequisites of Rule 23.

The downside is that a collective action can be considerably more expensive to manage and litigate, particularly for a class of 1.5 million members. For example, rather than having a representative group of plaintiffs answer discovery requests and appear for depositions, defense attorneys often demand answers to interrogatories for and depositions of every member of the collective action. This can raise the fees and costs for all counsel involved.

In addition, the opt-in collective-action procedure is intimidating for many employees at the initiation of litigation. Although the named plaintiffs mustered up the courage to take a stand on behalf of the collective group, other employees may fear retaliation or be less likely to want to go on public record to challenge the employer in court. In this respect, employment class actions are very different from other types of class actions, such as those involving consumer or securities law. Whereas consumers or investors can simply purchase from another company or go without the product in question, many employees do not want to risk unemployment and may not be able to move to another employer if they lose their jobs. For many women, in particular, claiming pay discrimination or suing their employer can be career suicide.

Rather than requiring plaintiffs to opt in with signed consent forms, the statute could be changed to an "opt-out" procedure. After finding that the plaintiffs are similarly situated, the court could authorize notice about the case to members of the collective action and advise them that they must opt out of the action. This type of modified collective action would provide greater efficiency and lower cost while accommodating fears that many employees may have about joining the lawsuit.

\section{d. Damages}

Under the EPA, prevailing plaintiffs may recover double damages: the amount of the pay disparity, plus liquidated damages in an equal amount. ${ }^{229}$ If the plaintiff proves a willful violation of the EPA, the statute of limitations may be extended an additional year to allow for three years of damages rather than two. ${ }^{230}$ Under Title VII, prevailing plaintiffs may recover the amount of the pay disparity plus compensatory and punitive damages, which are capped depending on the size of the employer. ${ }^{231}$

\footnotetext{
more lenient, and indeed, materially different, than the standard for granting class certification under Fed. R. Civ. P. 23.").

22929 U.S.C. $§ 216($ b) (2006).

23029 U.S.C. § 255(a) (2006).

23142 U.S.C. § 1981a(a)(1), (3)(A)-(D) (2006).
} 
The PFA would permit unlimited compensatory and punitive damages under the EPA. ${ }^{232}$ This provision is perhaps the least important and most controversial provision in the proposed PFA. As other scholars have noted, the Act likely failed to pass because of the enhanced damages provision. ${ }^{233}$ But the availability of enhanced damages is meaningless when most women are recovering nothing at all because they typically lose their cases for procedural reasons on summary judgment because of the prima facie standard or the factor-other-than-sex affirmative defense.

The enhanced damages provision was added to the PFA for several reasons. First, women who discover that they have received less pay than their male coworkers for performing the same job undoubtedly suffer from emotional distress. They feel betrayed and humiliated and may experience a range of serious psychological symptoms. Second, plaintiffs who allege pay discrimination based on race or national origin are entitled to receive unlimited compensatory and punitive damages under other federal statutes, but women who allege pay discrimination based on sex are not. ${ }^{234}$ Third, the possibility of tougher penalties would perhaps be a stronger incentive for employers to engage in voluntary compliance to avoid litigation.

Although enhanced damages would provide more complete relief to women who experience unjustified pay disparities, the addition of compensatory and punitive damages would complicate the streamlined nature of an EPA case. Although the amount of the backpay can be easily determined through payroll records, compensatory damages require individualized testimony to prove emotional harm. As Wal-Mart demonstrates, the addition of individualized proof to a group action may hamper the case. Indeed, Plaintiffs in Wal-Mart waived their right to compensatory damages under Title VII and sought only backpay because of the individualized proof issues that would be required.

There are other ways to accomplish enhanced damages in equal pay cases without adding the complexity involved in proving compensatory and punitive damages. First, in the age of computerized personnel records, the two-year (or three for willful violations) statute of limitations on equal pay claims could be extended. Many women who file equal-pay claims have worked for their employers for many years or even decades. Consider

232 Porter \& Vartanian, supra note 20, at 202.

Id.

234 See A Fair Share for All: Pay Equity in the New Am. Workplace: Hearing Before the S. Comm. on Health, Educ., Labor and Pensions, 110th Cong. 6 (2010) (statement of Stuart J. Ishimaru, Acting Chairman, U.S. EEOC), available at http://help.senate.gov/imo/media/doc/Ishimaru.pdf (testifying that enhanced damages provisions would put "gender based pay discrimination on a more equal footing with pay discrimination on other bases such as race"). 
the experience of women like Lilly Ledbetter, who worked for nineteen years at lower pay than her male co-workers. The statutes of limitations for pay-discrimination claims under both Title VII ${ }^{235}$ and the EPA ${ }^{236}$ remain very short given the long spans of time that many women receive unequal pay for equal work.

Another way to provide enhanced damages for willful equal-pay violations would be to add a higher multiplier to the backpay award. Under the liquidated damages provision in the EPA, a prevailing plaintiff receives two times the amount of backpay owed.237 The statute could include a higher liquidated damages multiplier. Some state wage-payment statutes, for example, provide for treble rather than double damages. ${ }^{238}$

Ultimately, however, the primary goal should be a workable paydiscrimination remedy under which women with meritorious claims can survive procedural hurdles and summary judgment and recover at least the amount of the pay disparity, plus liquidated damages and the costs involved in bringing a successful suit.

\section{CONCLUSION}

The decision in Wal-Mart offers valuable lessons to policymakers about the legal quest for equal pay. First, the law needs to catch up with the realities of how most pay discrimination occurs in the modern workplace. As experienced by the women at Wal-Mart, and as supported by volumes of research, pay discrimination frequently results from pay systems thatlike the compensation scheme in Wal-Mart-invest excessive, unchecked discretion in the hands of individual supervisors. Such systems allow a host of cognitive, social, and situational dynamics to skew wage decisions against women. To address this pervasive problem, Congress should adopt

23542 U.S.C. § 2000e-5(e)(1) (2006). Under the Lilly Ledbetter Fair Pay Act, a person may file a charge of pay discrimination within 180 days - or, in some states that have work-sharing agreements with the EEOC, 300 days - of any of the following: "[(1)] when a discriminatory compensation decision or other practice is adopted"; "[(2)] when an individual becomes subject to a discriminatory compensation decision or other practice"; or " $[(3)]$ when an individual is affected by application of a discriminatory compensation decision or other practice, including each time wages, benefits, or other compensation is paid, resulting in whole or in part from such a decision or other practice." 42 U.S.C. § 2000e-5(e)(3)(A) (Supp. III 2010).

236 The statute of limitations for EPA claims is two years, or three years for willful violations. 29 U.S.C. $§ 255$ (a) (2006). Unlike Title VII, plaintiffs may file EPA claims directly in court and need not file a charge with the EEOC.

237 Id. $\S 216(\mathrm{~b})$.

${ }^{238}$ See, e.g., MASS. GEN. LAWS ch. 149, § 150 (2010) (mandating treble damages for prevailing plaintiffs in wage cases). 
incentives for self-regulation by employers, such as pay transparency and periodic pay audits, in exchange for certain affirmative defenses in paydiscrimination litigation.

Second, women need a more workable litigation remedy for pay discrimination. The PFA is a step in that direction because it clarifies that the "factor-other-than-sex" must be a "bona fide factor-other-than-sex" that is job-related and consistent with business necessity. Even with this important change, however, a problem left unaddressed is the prima facie standard of "equal work" under the EPA, which often causes women to lose EPA claims. In addition, Wal-Mart highlights the steep procedural hurdles that women face in joining together to challenge widespread pay disparities. Wal-Mart should be overturned with a provision that clarifies that a compensation scheme that results in substantial gender pay disparities because of excessive, unchecked discretion in the hands of supervisors constitutes a general policy of discrimination sufficient to establish commonality under Rule 23. Alternatively, the collective action procedure under the EPA could be modified to a presumptive opt-out procedure.

Unless and until equal-pay laws are modernized, women who experience unjustified pay disparities will continue to be harmed twice: once by their employers, and again by federal laws that promise equal pay for equal work and court protection, but deliver only defeat and disappointment. 